\title{
Climatic variation in Africa and Europe has combined effects on timing of spring migration in a long-distance migrant Willow Warbler Phylloscopus trochilus
}

\author{
Magdalena Remisiewicz ${ }^{\text {Corresp., } 1,2}$, Les G. Underhill ${ }^{2,3}$ \\ ${ }^{1}$ Bird Migration Research Station, Faculty of Biology, University of Gdańsk, Gdańsk, Poland \\ 2 Animal Demography Unit, Department of Biological Sciences, University of Cape Town, Cape Town, South Africa \\ 3 Biodiversity and Development Institute, Cape Town, South Africa \\ Corresponding Author: Magdalena Remisiewicz \\ Email address: magdalena.remisiewicz@ug.edu.pl
}

Background. The arrival of many species of migrant passerine in the European spring has shifted earlier over recent decades, attributed to climate change and rising temperatures in Europe and west Africa. Few studies have shown the effects of climate change in both hemispheres though many long-distance migrants use wintering grounds which span Africa. The migrants' arrival in Europe thus potentially reflects a combination of the conditions they experience across Africa. We examine if the timing of spring migration of a long-distance migrant, the Willow Warbler, is related to large-scale climate indices across Africa and Europe.

Methods. Using data from daily mistnetting from 1 April to 15 May in 1982-2017 at Bukowo (Poland, Baltic Sea coast), we developed an Annual Anomaly metric (AA, in days) to estimate how early or late Willow Warblers arrive each spring in relation to their multi-year average pattern. The Willow Warblers' spring passage advanced by 5.4 days over the 36 years. We modelled AA using 14 potential explanatory variables in multiple regression models. The variables were the calendar year and 13 large-scale indices of climate in Africa and Europe averaged over biologically meaningful periods of two to four months during the year before spring migration.

Results. The best model explained $59 \%$ of the variation in AA with seven variables: Northern Atlantic Oscillation (two periods), Indian Ocean Dipole, Southern Oscillation Index, Sahel Precipitation Anomaly, Scandinavian Index and local mean temperatures. The study also confirmed that a long-term trend for Willow Warblers to arrive earlier in spring continued up to 2017.

Discussion. Our results suggest that the timing of Willow Warbler spring migration at the Baltic Sea coast is related to a summation of the ecological conditions they had encountered over the previous year during breeding, migration south, wintering in Africa and migration north. We suggest these large-scale climate indices reflect ecological drivers for phenological changes in species with complex migration patterns and discuss the ways in which each of the seven climate indices could be related to spring migration at the Baltic Sea coast. 
1 Climatic variation in Africa and Europe has combined effects on timing of spring

2 migration in a long-distance migrant Willow Warbler Phylloscopus trochilus

3

4 Magdalena Remisiewicz ${ }^{1,2}$, Les G. Underhill ${ }^{2,3}$

5

$6{ }^{1}$ Bird Migration Research Station, Faculty of Biology, University of Gdańsk, Wita Stwosza 59,

7 80-308, Gdańsk, Poland; https://orcid.org/0000-0002-3613-5738

$8{ }^{2}$ Animal Demography Unit, Department of Biological Sciences, University of Cape Town,

9 Rondebosch, 7701, South Africa; https://orcid.org/0000-0002-8758-1527

$10{ }^{3}$ Biodiversity and Development Institute, Unit 4, Gunner's Park, Gunner's Circle, 7475, South

11 Africa

12

13 Corresponding Author:

14 Magdalena Remisiewicz

15 Email address: magdalena.remisiewicz@ug.edu.pl 


\section{ABSTRACT}

18 Background. The arrival of many species of migrant passerine in the European spring has shifted earlier over recent decades, attributed to climate change and rising temperatures in Europe and west Africa. Few studies have shown the effects of climate change in both hemispheres though many long-distance migrants use wintering grounds which span Africa. The migrants' arrival in Europe thus potentially reflects a combination of the conditions they experience across Africa. We examine if the timing of spring migration of a long-distance migrant, the Willow Warbler, is related to large-scale climate indices across Africa and Europe. Methods. Using data from daily mistnetting from 1 April to 15 May in 1982-2017 at Bukowo (Poland, Baltic Sea coast), we developed an Annual Anomaly metric (AA, in days) to estimate how early or late Willow Warblers arrive each spring in relation to their multi-year average pattern. The Willow Warblers' spring passage advanced by 5.4 days over the 36 years. We modelled AA using 14 potential explanatory variables in multiple regression models. The variables were the calendar year and 13 large-scale indices of climate in Africa and Europe averaged over biologically meaningful periods of two to four months during the year before spring migration.

Results. The best model explained 59\% of the variation in AA with seven variables: Northern Atlantic Oscillation (two periods), Indian Ocean Dipole, Southern Oscillation Index, Sahel Precipitation Anomaly, Scandinavian Index and local mean temperatures. The study also confirmed that a long-term trend for Willow Warblers to arrive earlier in spring continued up to 2017.

Discussion. Our results suggest that the timing of Willow Warbler spring migration at the Baltic Sea coast is related to a summation of the ecological conditions they had encountered over the previous year during breeding, migration south, wintering in Africa and migration north. We suggest these large-scale climate indices reflect ecological drivers for phenological changes in species with complex migration patterns and discuss the ways in which each of the seven climate indices could be related to spring migration at the Baltic Sea coast. 


\section{INTRODUCTION}

Environmental conditions have changed in recent decades as a consequence of global climate change and these changes have had knock-on effects in the timing of the life stages of plants and animals (e.g. Walther et al., 2002; Vose, Easterling \& Gleason, 2005; Peñuelas, 2009).

Phenological changes in bird migrations are one of the best-described animal responses to climate change in the northern hemisphere (e.g. Miller-Rushing et al., 2008; Wood \& Kellermann, 2015; Miles et al., 2017; Zaifman et al., 2017; Lehikoinen et al., 2019). The timing of many passerines' arrival in the European spring has shifted earlier in recent decades (e.g. Sokolov et al., 1998; Hüppop \& Hüppop, 2003; Vähätalo et al., 2004; Tøttrup, Thorup \& Rahbek, 2006a; Miles et al., 2017), which is mostly linked to increasing spring temperatures (Lehikoinen et al., 2019).

Most long-distance migrants breeding in Europe winter in the southern hemisphere, but few studies have sought to understand the effects on migrants of climate change in both hemispheres (Altwegg et al., 2012; Ockendon, Leech \& Pearce-Higgins, 2013; Bussière, Underhill \& Altwegg, 2015). Advances in spring arrival in Europe have been related to the winter and annual North Atlantic Oscillation Index (NAOI), which reflect weather patterns in western Europe and northern Africa (Forchhammer, Post \& Stenseth, 2002; Møller, 2002; Cotton, 2003; Stenseth et al., 2003; Ahola et al., 2004; Gordo, Barriocanal \& Robson, 2011; Grimm et al., 2015). NAOI explained only $0 \%-6 \%$ of the variance in the phenology of spring migration in 23 species of migrants in Helgoland, Germany (Haest, Hüppop \& Bairlein, 2018), probably because this index does not reflect the conditions the migrants experience farther south. Most studies have used temperatures and rainfall from locations the birds likely visit (Saino \& Ambrosini, 2008; Pasinelli et al., 2011; Halupka et al., 2017) and the Normalized Difference Vegetation Index (NDVI) (Tøttrup et al., 2012; Jørgensen et al., 2016; Thorup et al., 2017) as proxies for the ecological conditions that the migrants encounter in Africa. Few studies have used the Sahel Precipitation Anomaly (SAH) (e.g. Zwarts et al., 2009; Tobolka et al., 2018) as a proxy for rainfall in the Sahel, where many European migrants stop over or stay for winter. The relationship between the timing of migration and the El-Niño-Southern Oscillation has been marginally explored (ENSO/SOI) (e.g. Stenseth et al., 2003; MacMynowski \& Root, 2007; Miller-Rushing et al., 2008), as has the Indian Ocean Dipole (IOD) (e.g.Hušek et al., 2008; Zduniak et al., 2010; Tryjanowski, Stenseth \& Matysioková, 2013; Tobolka et al., 2018). The 
SOI and IOD are continental-scale weather anomalies which are correlated with rainfall and temperatures in the southern hemisphere (Black, 2005; Marchant et al., 2006), thus they might serve as useful indices that reflect the conditions which migrant European birds experience in eastern and southern Africa.

Changes in the timing of a bird's life stages which occur on the southern non-breeding grounds will likely have carry-over effects on subsequent stages, including stages on the northern breeding grounds (Peach, Baillie \& Underhill, 1991; Gordo, 2007; Barshep et al., 2011; Conklin \& Battley, 2012; Tobolka et al., 2018; Tomotani et al., 2018). Birds which migrate between Eurasia and Africa adjust the timing of their moult and pre-migratory fattening to the conditions at their non-breeding grounds in Africa (Salewski et al. 2004; Zwarts et al. 2009; Altwegg et al. 2012; Tomotani et al. 2018; Remisiewicz et al. 2019). Weather, which determines food availability on the non-breeding grounds, affects pre-migratory preparations by the migrants, and thus might influence their departure time and migration strategy (Katti \& Price, 1999; Saino \& Ambrosini, 2008; Studds \& Marra, 2011; Ouwehand \& Both, 2017). Environmental conditions at autumn and spring migration stopover sites also influence the timing of spring arrival at the breeding grounds (Tøttrup et al. 2012; Halupka et al. 2017). Demographic parameters at the breeding sites of long-distance migrants, such as White Storks Ciconia alba and Red-backed Shrikes Lanius collurio, reflect a carry-over effect of environmental conditions at their stopover sites and at their wintering grounds in Africa (Hušek et al., 2008; Tobolka et al., 2018).

Certain long-distance migrant passerines, such as Red-backed Shrike, Barn Swallow Hirundo rustica, European Reed Warbler Acrocephalus scirpaceus, Sedge Warbler A. schoenobaenus, Spotted Flycatcher Muscicapa striata, Garden Warbler Sylvia borin and Willow Warbler Phylloscopus trochilus, breed in Europe and occupy non-breeding grounds which span most of Africa south of the Sahara Desert (Cepák et al., 2008; Fransson \& Hall-Karlsson, 2008; Bairlein et al., 2014; Valkama et al., 2014). In many migrants, the populations or subspecies which use different wintering grounds meet at the breeding grounds in Europe, such as White Stork (Tobolka et al., 2018), Blackcap Sylvia atricapilla and Willow Warbler (Bensch et al., 2009; Bensch, Liedvogel \& Åkesson, 2011). Thus these species’ patterns of spring arrival in Europe should reflect a combination of the diverse conditions they experience across their nonbreeding areas. So far few studies have examined if and how the combined effects of conditions which different migratory populations of a species encounter at their various non-breeding 
107 grounds and stopover sites affect their arrival and performance at the breeding grounds (Saino et

108 al., 2007; Tobolka et al., 2018). Uncovering the complex relationships between climatic variation

109 at a global scale and the migration patterns of migratory birds is crucial to understand the effects

110 of climate change on the seasonal timing and population trends of these wide-ranging species

111 (Hayhow et al., 2014). This study explores this phenological pattern of a long-distance migrant

112 passerine, the Willow Warbler, which we chose as a case study. We aimed to examine if the

113 timing of the Willow Warbler's spring migration at the Baltic Sea coast had responded to large-

114 scale climate variables affecting the widespread non-breeding grounds in the year before their

115 migration.

117 MATERIALS \& METHODS

118 Study species

119 Our choice of the Willow Warbler as a study species was motivated by the availability of

120 detailed information about the timing of its spring migration to northern Europe at a stopover site

121 on the Baltic Sea coast. Different populations of this species migrate to their breeding grounds in

122 Scandinavia and the Baltic region 5000-12000 km from their wintering grounds south of the

123 Sahara Desert in west, central, east and southeast Africa (Cramp \& Brooks, 1992; Fransson \&

124 Hall-Karlsson, 2008; Zwarts et al., 2009; Valkama et al., 2014; Lerche-Jørgensen et al., 2017;

125 Maciąg et al., 2017).

126 Two subspecies of Willow Warbler breed in northern and central Europe, then migrate

127 across the Baltic Sea region, including Bukowo. Phylloscopus trochilus trochilus breeds in

128 southwestern Scandinavia, most of Poland, and western and southern Europe, then migrates

129 mostly to west and central sub-Saharan Africa; Ph. t. acredula breeds in northeastern

130 Scandinavia, eastern Poland and northeast of these areas, then migrates mostly to central, eastern

131 and southern Africa (Fig. 1) (Tomiałojć \& Stawarczyk, 2003; Bensch, Bengtsson \& Åkesson,

132 2006; Fransson \& Hall-Karlsson, 2008; Bensch et al., 2009; Zwarts et al., 2009; Valkama et al.,

133 2014; Lerche-Jørgensen et al., 2017). The proportions of the two Willow Warbler subspecies

134 which migrate through Bukowo are difficult to estimate because the differences in colour and

135 size between them are clinal (Bensch et al., 2009). Willow Warblers which stop over at the

136 Polish coast originate from Sweden and Finland, and probably from other Baltic countries

137 (Maciąg et al., 2017). Given that Bukowo lies close to the migratory divide between the two 
138 subspecies of Willow Warblers across Sweden and eastern Poland (Fig. 1) (Bensch et al., 2009),

139 we assumed that we caught both subspecies. Willow Warblers from the western part of the

140 breeding grounds migrate mostly to west Africa, but the proportion of Willow Warblers which

141 use non-breeding grounds in eastern and southeastern Africa increases eastwards across their

142 breeding grounds (Zwarts et al., 2009). The farthest ringing recoveries of Willow Warblers

143 ringed at the Polish coast and elsewhere in Poland come from the Iberian Peninsula in the west

144 and Egypt in the east, thus these recoveries reflect the species' migration routes, not their

145 wintering grounds south of the Sahara (Maciąg et al., 2017). Willow Warblers from Sweden and

146 Finland, which pass through Bukowo, use wintering grounds in west, central, east and southeast

147 Africa, as far as South Africa (Fransson \& Hall-Karlsson, 2008; Valkama et al., 2014). Based on

148 these established links, the Willow Warblers migrating along the Polish coast in spring have non-

149 breeding grounds in western, eastern and southern Africa. We therefore expected that the timing

150 of Willow Warblers' northward migration at Bukowo would be affected by the large-scale

151 climate indices which reflect conditions across Africa.

152 Willow Warblers inhabit trees and bushes, from wooded savannah to riparian thickets,

153 and feed mainly on insects and spiders which they pick from vegetation, supplemented by berries

154 (Cramp \& Brooks, 1992; Zwarts et al., 2009). They arrive in central and northern Europe,

155 including the Baltic Sea coast, in April-May, breed in June-July, depart from the breeding

156 grounds in August-September, migrate south in August-October and occupy their non-breeding

157 grounds in Africa in November-March (Fig. 1) (Cramp \& Brooks, 1992; Herremans, 1999;

158 Tomiałojć \& Stawarczyk, 2003; Dean, 2005; Zwarts et al., 2009). Our study site is in the

159 northern hemisphere, and we use boreal seasons throughout this paper: "spring migration" is

160 April-May, "autumn migration" is August-October and "winter" is November-March.

161

162 Study site and sampling

163 We analysed the daily numbers of Willow Warblers ringed during spring migration using

164 standardised mistnetting protocols at Bukowo ringing station on the Baltic Sea coast

165 (54²0'13"N, 16²14'36"E) in 1982-2017 (Table S1, Supplementary Information). Migrating

166 passerines were caught in mist nets located on spits between the Baltic Sea and the Bukowo and

167 Kopań coastal lakes. The habitat composes mixed coastal and riparian forests with an

168 undergrowth of fruit bushes, and willow bushes and reedbeds along the margins of the lakes 
169 (Nowakowski et al., 2012). Birds were caught from dawn until dusk using 35 to 59 8-m long 170 mist nets. The number of nets was stable during each season, but changed between years.

171 Mistnetting and ringing were conducted daily from dawn to dusk, from the last week of March to 172 mid-May. All birds caught were ringed, aged and measured, then released. The same standard 173 fieldwork protocol was used annually (Busse \& Meissner, 2015). In spring, adult and immature 174 Willow Warblers are all in the same plumage and were aged as "full grown" (Svensson, 1992; 175 Demongin, 2016), thus we treated them jointly in our study. Our analysis is based on birds 176 ringed between 1 April and 15 May. The earliest date a Willow Warbler has been captured at 177 Bukowo was 2 April 2017. We took 15 May as the end of the study period; after this date, 178 frequent recaptures of the same birds indicated that they were local breeders (Supplement 2). In 179 our analyses we used the daily totals of ringed Willow Warblers based on the first captures of 180 Willow Warblers and ignoring recaptures. This protocol enabled us to quantify the timing of 181 Willow Warblers' spring migration at the Baltic Sea coast of Poland. Our catching and ringing of 182 birds was conducted with the authorisation of the Polish Academy of Sciences, with the approval of the General Directorate for Environmental Protection, Poland (DZPWG.6401.03.97.2017.jro). Field research at Bukowo was approved by the Marine Office, Słupsk (OW-A-510/87/17/ds).

\section{Climate indices}

We used 13 large-scale and local climate indices as proxies for the ecological conditions (Stenseth et al., 2003) which the Willow Warblers had encountered during the year preceding their spring migration at the Baltic Sea coast (Fig. 1, Table 1). These indices reflect conditions at the breeding grounds in north Europe, on southward migration, at the wintering grounds in Africa and on northward migration from Africa across Europe. The Scandinavian pattern (SCAND) reflects the primary circulation centre over Scandinavia; its positive phase in summer is associated with low precipitation and high temperatures (Bueh \& Nakamura, 2007). The North Atlantic Oscillation Index (NAOI) reflects the weather patterns over Europe and west Africa; positive winter values are related to warm and wet winters in west Africa and early springs in western Europe (Hurrell, 1995). The Sahel Precipitation Anomaly (SAH) reflects rainfall in the Sahel region; positive values are associated with higher-than-average rainfall (Munemoto \& Tachibana, 2012). The El Niño-Southern Oscillation Index (SOI) reflects the El Niño and La 
200 Niña phases of circulation in the eastern Pacific Ocean, which affect weather in southern Africa; 201 negative SOI values indicate an El Niño, associated with below-average rainfall across southern 202 Africa (Saji \& Vinayachandran, 1999; Stenseth et al., 2003). The Indian Ocean Dipole (IOD) is

203 the gradient between sea surface temperatures in the eastern and western Indian Ocean; when the 204 IOD is positive east and southeastern Africa receive above-average rainfall (Marchant et al., 205 2006; Schott, Xie \& McCreary, 2009). The IOD is sometimes in phase with SOI but is frequently 206 independent (Ashok, Guan \& Yamagata, 2003; Marchant et al., 2006; Schott, Xie \& McCreary, 207 2009). We downloaded monthly values of these indices for 1981-2017 from databases of the US 208 National Oceanic and Atmospheric Administration, National Weather Service, Climate 209 Prediction Center (http://www.cpc.ncep.noaa.gov/). We also downloaded mean daily 210 temperatures for Łeba $\left(54^{\circ} 45^{\prime} \mathrm{N}, 17^{\circ} 32^{\prime} \mathrm{E}\right)$, the nearest coastal weather station to Bukowo, located $21195 \mathrm{~km}$ east and similarly exposed to local marine weather, from the European Climate 212 Assessment and Dataset (http://www.ecad.eu). From these daily temperatures we calculated the 213 mean temperature at Leba for April-May (LEB Apr-May), which increased on average by $1.5^{\circ} \mathrm{C}$ 214 over the 36 years of our study (Table S2, Table S3). We used this temperature as a proxy for 215 local ecological conditions on the birds' arrival in spring at Bukowo, as in other studies on 216 Willow Warbler spring phenology (Sokolov et al., 1998; Palm et al., 2009).

The selected weather indices represented climatic variation across the wide geographical range which different populations of Willow Warblers visit during their annual cycle. We constructed an annual time series for each climate variable by selecting the biologically meaningful months (Fig. 1) and averaging the values for these months: 1) spring arrival at the Baltic Sea coast occurs in April-May, we therefore averaged NAOI and mean temperature in Łeba for April-May of the same year; 2) wintering in Africa occurs from November of the previous year to March, so we averaged NAOI, SAH, IOD and SOI for the preceding November-March; 3) migration from northern Europe to Africa occurs in August-October of the previous year, thus we averaged SCAND, NAOI, SAH, IOD and SOI for the previous AugustOctober; 4) the previous stay at the breeding grounds occurs in the preceding June-July, we thus averaged SCAND and NAOI for June-July of the previous year. We generated 13 climate indices (Table 1) and used these as explanatory variables in a multiple regression model to estimate the influence of climate on the timing of Willow Warblers' arrival in spring at the Baltic Sea coast. The SAH in August-October and IOD in November-March increased, and June-July 
231 NAOI decreased over the 36 years of our study (Table S2, Table S3). The averaged NAOI

232 indices in subsequent periods were not correlated, nor were the SAH and SCAND indices (Table

233 S2). The IOD in November-March was correlated with IOD in August-October, and with NAOI

234 and SAH in this period, and a few indices were correlated with each other and with the year

235 (Table S2). We considered the correlations between these variables in our statistical approach,

236 being aware of the hazards of multicollinearity (Dormann et al., 2013).

237

238

\section{Statistical analyses}

239

We excluded the springs of 1993 and 2011, when fewer than 30 Willow Warblers were caught at

240

Bukowo; thus the data for analyses included 34 years with at least 31 birds caught in a spring

241

(Table S1). We imputed missing data for days when mistnetting was suspended for reasons such

242 as heavy storms, as done in similar studies (Sokolov et al., 1998; Tøttrup, Thorup \& Rahbek, 2006a; Redlisiak, Remisiewicz \& Nowakowski, 2018). For a given date, missing values were imputed using the mean number of birds ringed on that date in the six years before and after the year with the missing value (Redlisiak, Remisiewicz \& Nowakowski, 2018). These occurred in two years and constituted at most four days per spring.

For each spring we calculated the annual accumulative curve, defined as the cumulative daily percentage of the numbers of Willow Warblers mistnetted that season, and used these curves to compare the timing of migration between years. We also computed the dates when 10\% (beginning), 50\% (median) and 90\% (end) of migration occurred in each spring between 1982 and 2017. We calculated the duration of spring migration as the difference (in days) between the dates of $10 \%$ and $90 \%$ of migrant passage (Miles et al., 2017; Lehikoinen et al., 2019). To examine the long-term trend in the timing of Willow Warbler spring migration, we calculated the linear least square regressions of these percentiles and the duration against year (Tøttrup, Thorup \& Rahbek, 2006a; Miles et al., 2017).

The date of each percentile reflects the timing for that stage of the spring passage, but does not reflect the overall migration pattern in a season. To quantify the extent to which the overall migration pattern in a particular spring was "early" or "late" in relation to the overall multi-year pattern, we developed the Annual Anomaly (AA), measured in days. We calculated the average cumulative curve based on the daily catches in all years. This provided the overall 
262 the area between the cumulative curve for that year and the average curve (Fig. 2, Fig. S1),

263 following Crawford et al. (1990) and Nowakowski et al. (2005). We estimated the AA as the

264 sum of the daily differences between the two curves over the 45 days of the spring migration

265 (Fig. 2). This area can be positive or negative. A negative value for AA indicated that negative

266 daily differences prevailed, and thus the passage in that year was earlier than the multi-year

267 average pattern; a positive AA indicated the passage was later than the average (Fig. 2, Table S1,

268 Fig. S1). This is analogous to studies analysing trends in the dates of percentiles of passage,

269 where a negative trend indicates an advance of passage over the years and a positive trend means

270 a delay (Tøttrup, Thorup \& Rahbek, 2006a; Miles et al., 2017; Lehikoinen et al., 2019). AA can

271 take values between -45 , which would be the maximum possible advance of passage over the 45

272 days of the spring season, and +45 , the maximum possible delay.

273 The linear regression of AA over the years describes the long-term trend in the timing of

274 Willow Warblers' spring migration at the Polish coast, expressed as the integrated deviation

275 from the long-term average pattern. To investigate the effect of climatic variation on the timing

276 of the arrival of Willow Warblers in spring, we used the AA as the response variable in multiple

277 linear regression models in which the year and the 13 climate variables which we chose (Table 1)

278 were explanatory variables.

279 The AA and the climate indices were time series, so they potentially contained

280 autocorrelations between successive values (Cowpertwait \& Metcalfe, 2009; Crawley, 2013;

281 Simmons et al., 2015; Barshep et al., 2017). The missing values of the AA (in 1993, 2011) were

282 imputed for the autocorrelation tests, with the values predicted from their regression trend

283 against the years (Crawley, 2013). We tested for any significance of autocorrelations in our time

284 series for lags of up to 10 years by using a portmanteau Ljung-Box Q-test to test the null

285 hypothesis of independence (a lack of autocorrelations) in the analysed data series (Ljung \&

286 Box, 1978). The autocorrelations were not significant for any variable (Table 1), so we were able

287 to use standard regression analyses.

288 We standardised the Annual Anomaly and the climate variables so that each had a mean

289 of 0 and a standard deviation of 1 . Then we checked for any correlations between the climate

290 variables using Pearson's correlation coefficient (Table S2). All correlation coefficients but one

291 were $|\mathrm{r}|<0.62$ (Table S2), which indicated no strong multicollinearity (Dormann et al., 2013).

292 We retained the year as the explanatory variable in our model, though it was correlated with a 
293 few climate variables (Table S2), to control for the effect of the year while estimating the effects

294 of the climate variables on AA (Frost, 2019). To assess the multicollinearity of all the

295 explanatory variables in the full and the best models we used the variance inflation factor (VIF)

296 (Dormann et al., 2013, Sparks \& Tryjanowski, 2005; Marchowski et al., 2017) in the R package

297 “car 2.1-6" (Fox \& Weisberg, 2011). Some studies have used NAOI as a quadratic term (Møller,

298 2002; Grimm et al., 2015), thus we compared models of AA regression against each climate

299 variable used as a linear or as a quadratic term, using AICc, to determine which use would

300 produce better models. After this comparison, we chose to use all climate variables in linear

301 terms. We used multiple linear regression with the Annual Anomaly (AA) as the response

302 variable with the year and the 13 climate indices as the explanatory variables to estimate any

303 relationship between the indices and the timing of the spring passage of Willow Warblers at the

304 Baltic Sea coast. We were aware of the issue of multicollinearity in our modelling and thus

305 carefully observed the process and its outputs. We inspected the residuals to check if the full and

306 the best models met the assumptions of the multiple regression (Crawley, 2013). Using "all

307 subsets regression" we selected the best model by Akaike Information Criteria corrected for

308 small sample size (AICc), using the package "MuMIn 1.43.6" (Bartoń, 2019). To verify the

309 choice of the best model, we also used "stepwise backward" selection by AIC in the package

310 "MASS 7.3-49" (Venables \& Ripley, 2002). To check if the best model was not overfitted, we

311 plotted residuals from the model with six variables against each remaining seventh variable

312 (Frost, 2019). We estimated the proportion of variation explained by the best model using the

313 adjusted coefficient of determination (AdjR ${ }^{2}$ ). Using the package "heplots 1.3-3" (Fox, Friendly

314 \& Monette, 2007), we also calculated partial regression coefficients (partial $\mathrm{R}^{2}$ ) in the multiple

315 regression models. The partial $\mathrm{R}^{2}$ estimates the proportion of variation explained by each

316 variable in the model. The statistical analyses were conducted in R 3.4.4 (R Core Team, 2018).

\section{RESULTS}

319 Long-term trends in timing of Willow Warblers' spring migration at Baltic Sea coast

320 The timing of Willow Warblers' spring migration at Bukowo advanced by eight days for the start

$321(10 \%)$ of the passage, by eight days for the median (50\%) and by five days for the end (90\%).

322 All three of these were statistically significant (Fig. 3A, Table S4). Because the date for the first

$32310 \%$ of birds advanced more than the date for the last $90 \%$, the duration of the spring passage of 
$32480 \%$ of migrants $(10 \%-90 \%)$ through Bukowo extended by six days on average over the 36

325 years of the study (Fig. 3A, Table S4). As measured by the Annual Anomaly (AA), spring

326 migration advanced by 0.15 days a year $(t=8.68, P=0.006)$, or 5.4 days over the 36 years (Fig.

327 3B, Table S4). Though significant, the linear trend explained only $32 \%$ of the variation in the

328 starting dates of migration, $20 \%$ of variation in the median dates and $21 \%$ of the variation in AA

329 (Table S4), which varied greatly between years (Fig. 3B, Table S1). The extremes in AA

330 occurred in 1989 (seven days early relative to the regression line) and in 1997 (five days late)

331 (Fig. 3B, Table S1).

332

333

334

The relationship between the timing of Willow Warblers' spring migration at the Baltic

coast and large-scale climate indices

335 The full multiple regression model with AA as the response variable had 14 explanatory

336 variables (13 climate variables and year) (Table 1, Table S5). Values of VIF $<10$ for all

337 variables (Table S5) indicated no potentially harmful collinearity in our modelling (Dormann et

338 al., 2013). We used all climate variables as linear terms, because for most the linear models of

339 their relationships to AA were better than the quadratic models (Table S6). For NAOI in one

340 (June-July) of four analysed periods the quadratic model was better than the linear one ( $\Delta$ AICc $<$

$341-2$; Table S6), thus we used NAOI as a linear term for all the periods for consistency. The best

342 model with the smallest AICc value in the "all-subsets" approach (Table S7) had seven

343 explanatory variables and explained $\mathrm{Adj}^{2}=58.6 \%$ of the variation in the Annual Anomaly

344 (Table 2). We obtained the same best model using the "stepwise backward" selection, which

345 builds confidence that, given this set of candidate explanatory variables, we had selected a good

346 subset for the final best model we present. Inspection of residuals (Fig. S2, Fig. S3) showed that

347 the best model and the full model met the assumptions of multiple linear regression, and the best

348 model was well-fitted to the data (Crawley, 2013). Multicollinearity was not an issue in the best

349 model because the largest variance inflation factor (VIF) was 1.86, substantially less than the

350 guidance cut-off value of 10 (Table 2). SOI (August-October) explained $37 \%$ of the variation in

351 the IOD (August-October), according to their linear regression (Table S8), thus these two

352 indices largely varied independently though they were correlated (Table S2). The final best

353 model had seven variables, based on 34 data points (Table 2). In these circumstances a single

354 outlying value can result in an explanatory variable becoming significant. To confirm that 
355

356

357

358

359

360

361

362

363

364

365

366

367

368

369

370

371

372

373

374

375

376

377

378

379

380

381

382

383

384

385

overfitting was not an issue in this regression analysis, we performed seven regressions, each with six of the seven explanatory variables, and plotted the residuals from each regression against the missing explanatory variable (Fig. S4). In each case we obtained a well-behaved scatter plot showing a decreasing trend, with no outliers. In each plot it is clear that the inclusion of the missing explanatory variable is supported by the data (Fig. S4). Overall, the regression analysis can be characterised as satisfactory.

The year as a variable was not selected in the best-fitted model, indicating that the climate variables explained the multi-year trend in AA. The partial $R^{2}$ values ranged from 0.34 for the Indian Ocean Dipole (August-October) to 0.13 for the North Atlantic Oscillation Index (November-March) (Table 2). The signs of all the estimated regression coefficients were negative (Table 2). We can interpret these signs cautiously because most correlations between the seven variables included in the final model were not significant or relatively small (Table S2). When we accounted for the effects of other climate variables, the local April-May temperatures at Łeba were related to AA and migration advanced in warm springs (Table 2, Fig. 4A). Similarly, for each of the seven climate indices in the final model, the higher the value of the index, the earlier was the timing of spring migration (Table 2, Fig. 4). The relationships of AA to the SOI (August-October) and SAH (November-March), and to temperature in Łeba (April-May), when each was a single explanatory variable, were not significant (Fig. 4). These relations were revealed in the multiple regression model, which controlled for the effects of the other variables on AA (Table 2).

\section{DISCUSSION}

Two outcomes stand out in this study on the timing of Willow Warblers' spring migration at Bukowo on the Baltic Sea coast. The first outcome is novel: 59\% of the interannual variation in the timing was related to seven large-scale climate indices on the species' wintering and breeding grounds over the previous 12 months. This suggests that the timing of Willow Warbler spring migration at the Baltic Sea coast is a summation of the ecological conditions which they had encountered over the previous year during breeding, migration south, wintering in Africa and migration north. We discuss the ways in which each of the seven climate indices could be related to spring migration at the Baltic Sea coast. Secondly, the study confirmed that a long-term trend for Willow Warblers to arrive earlier in spring, reported from other sites in Europe but analysed 
386

387

388

389

390

391

392

393

394

395

396

397

398

399

400

401

402

403

404

405

406

407

408

409

410

411

412

413

414

415

416

over shorter periods (Sokolov et al., 1998; Cotton, 2003; Hüppop \& Hüppop, 2003; Tøttrup, Thorup \& Rahbek, 2006a; Hedlund et al., 2014; Miles et al., 2017), continued at Bukowo up to 2017. We discuss the potential causes of these shifts in the context of our results and the earlier studies.

\section{Timing of Willow Warbler spring migration in relation to local conditions in spring}

The earlier arrival of Willow Warblers in spring at Bukowo over 1982-2017 (Fig. 3) corresponds with the overall pattern for this species in Europe and shows that the advance in spring arrivals has continued. At the Baltic Sea island of Christiansø, Denmark, spring migration advanced in 1976-1997 by 0.25 days a year for the first 5\% of birds and by 0.24 days a year for the first 50\% (Tøttrup, Thorup \& Rahbek, 2006a); the equivalent values in our study were 0.27 and 0.17 days a year, and 0.22 for the first $10 \%$ of birds, a more robust metric than $5 \%$, considering our small samples (Fig. 3, Table S4). On the island of Gotland, Sweden, spring arrival of Willow Warblers advanced by $0.20-0.29$ days a year and egg-laying by 0.23 days a year in 1990-2012 (Hedlund et al., 2014). Spring migration of Willow Warblers also advanced in 1959-1990 at Rybachy, Russia, ca $220 \mathrm{~km}$ east of Bukowo on the Baltic coast (Sokolov et al., 1998), in 1960-2002 at Helgoland, North Sea, Germany (Hüppop \& Hüppop, 2003), in 1955-2014 at Fair Isle, Scotland (Miles et al., 2017), and in 1971-2000 in Oxfordshire, England (Cotton, 2003).

We found an increase in the duration of Willow Warblers' spring migration as a result of their passage starting earlier; this corresponds with similar patterns reported by Miles et al. (2017) and Lehikoinen et al. (2019) from other locations. The pattern of Willow Warblers' earlier arrival in spring at Bukowo was related to local mean April-May temperatures in Łeba (Fig. 4A), which increased over the 36 years of our study (Table S3). Our results correspond with other findings: the early arrivals of Willow Warblers at Rybachy and in Estonia were associated with high local temperatures in April and May (Sokolov et al., 1998; Palm et al., 2009). At Helgoland the earlier migration of Willow Warblers in spring coincided with higher mean annual temperatures locally (Hüppop \& Hüppop, 2003). However, these correlations between the early arrival of Willow Warblers and high local temperatures at ringing stations might not be a cause-effect relationship but rather the effect of both phenomena being related to high temperatures at an earlier stage of the birds' migration. A strong correlation between the dates of spring arrival of the first 5\% of Willow Warblers' at Hanko, Finland, and mean April 
417 temperatures in the Balkans and in the Middle East supports this premise (Halkka, Lehikoinen \&

418 Velmala, 2011). The advance of Willow Warblers' spring migration corresponds with a general

419 trend in Europe over the past few decades for migrants to arrive earlier in relation to global

420 warming and the resulting higher spring temperatures along the birds' migration routes (e.g.

421 Sokolov et al., 1998; Tryjanowski, Sparks \& Kuźniak, 2002; Cotton, 2003; Hüppop \& Hüppop,

422 2003; Ahola et al., 2004; Tøttrup, Thorup \& Rahbek, 2006a; Saino et al., 2007; Miles et al.,

423 2017; Lehikoinen et al., 2019). April-May temperatures at Łeba explained only 29\% of the

424 variation in Willow Warbler spring migration at Bukowo, but these temperatures and six large-

425 scale climate indices together explained $59 \%$ of the interannual variation (Table 2 ).

426 The average April-May NAOI explained $27 \%$ of the variation in the timing of spring

427 migration (Table 2, Fig. 4C); this contrasts with Palm et al. (2009) who found no relation

428 between the first arrival dates of Willow Warbler in Estonia in 1957-1996 and March-May

429 NAOI. But our results come from later years, when the effects of climate change have been more

430 pronounced (Simmons et al., 2017). Additionally, Willow Warblers begin arriving in the Baltic

431 region from April, thus the April-May NAOI which we used probably reflects conditions during

432 spring migration through Europe better than March-May. The April-May NAOI was not

433 correlated with mean April-May temperatures in Łeba (Table S2); thus each of these climate

434 variables explains a different aspect of the variation in the timing of spring migration at Bukowo.

435 In warm springs, with high April-May temperatures in Europe and high NAOI, early availability

436 of insects on passage would enable migrants to fuel quickly at stopovers, migrate faster and

437 arrive earlier at the breeding grounds (van Noordwijk et al., 2006; Gordo, 2007). Early-arriving

438 individuals occupy better-quality territories and have better breeding success than birds which

439 arrive later; thus there is selective pressure for early migration in warm and early springs (Kokko

440 et al., 2006; Gordo, 2007).

441

442

443

Interannual variation in timing of Willow Warblers' spring migration in relation to climate variability in west, east and southern Africa

444 In the tropics and sub-tropics rainfall has a greater effect on food abundance for birds than

445 temperature, in contrast to the temperate zones of the northern hemisphere (Elkins, 1988;

446 Newton, 2010). NAOI, SAH, SOI and IOD are related to rainfall and temperatures in Africa, and

447 thus with vegetation and ecological conditions on the migrants' passage and wintering areas (e.g. 
448 Hurrell, 1995; Stenseth et al., 2003; Marchant et al., 2006; Munemoto \& Tachibana, 2012; Heino

449 et al., 2018). Ecological conditions at the wintering grounds determine the body condition of

450 birds, influence their timing of moult and fuelling, and thus the timing of departure and the rate

451 of migration north (Katti \& Price, 1999; Salewski et al., 2004; González-Prieto \& Hobson, 2013;

452 McKellar et al., 2013; Ouwehand \& Both, 2017; Remisiewicz et al., 2019). Wet winters in

453 Africa produce an abundance of insects (Allan et al., 1997; Lingbeek et al., 2017; Thorup et al.,

454 2017) and enable migrants to fuel for migration quickly and to depart early (Peach, Baillie \&

455 Underhill, 1991; Studds \& Marra, 2011; Altwegg et al., 2012). Abundant food also enables the

456 migrants to moult early, leaving them time for efficient pre-migratory fuelling (Salewski et al.,

457 2004; Remisiewicz et al., 2019). Greenish Leaf Warblers Phylloscopus trochiloides fuelled

458 faster, accumulated greater fuel loads and departed earlier from their wintering grounds in

459 tropical India in wet years, when insects were more abundant, than in dry years (Katti \& Price,

460 1999). We suggest a similar pattern for Willow Warblers wintering in Africa. Large fuel reserves

461 on departure from the wintering grounds enable birds to migrate faster and with shorter stopovers

462 (Gordo, 2007; Zwarts et al., 2009; McKellar et al., 2013). In contrast, droughts at the wintering

463 and stopover sites in Africa delay the arrival in the European spring of long-distance migrants

464 such as Red-backed Shrike and Thrush Nightingale Luscinia luscinia (Tøttrup et al., 2012).

465 Temperatures at the wintering grounds might also influence food availability and thus the

466 migration timing of birds. Willow Warblers and other long-distance migrants arrived early in

467 Oxfordshire, UK, in spring after high temperatures during their wintering in Africa (Cotton,

468 2003). The breeding success of female White Storks in western Poland showed a relationship to

469 climate indices which reflect rainfall in west Africa (SAH) and in east Africa (IOD) in August-

470 September. Different storks use one or the other of these winter quarters (Tobolka et al., 2018).

471 We analysed climate indices for more areas across Africa and Europe occupied by our study

472 species at different life stages; thus we found a more complex combination of climate indices to

473 be related to their spring arrival in Poland than Tobolka et al. (2018) revealed for White Storks.

474 The large-scale climate indices reflect rainfall and temperatures in regions of Africa and Europe

475 used by different populations of Willow Warblers. We suggest that the relationships we found

476 between these indices and spring migration phenology of Willow Warblers at the Baltic Sea

477 coast reflect carry-over effects of ecological conditions which the different populations

478 encountered at locations they visited in the preceding year. 
The relation we found between November-March NAOI and Willow Warbler spring

480

481

482

483

484

485

486

487

488

489

490

491

492

493

494

495

496

497

498

499

500

501

502

503

504

505

506

507

508

509 migration (Table 2, Fig. 4E) corresponds with the early arrival of many species in Europe after a positive winter NAOI (December-February), related to warm and early springs (e.g. Forchhammer, Post \& Stenseth, 2002; Hüppop \& Hüppop, 2003; Ahola et al., 2004; Vähätalo et al., 2004; Rainio et al., 2006; Gordo, 2007; Jonzén et al., 2007; Saino \& Ambrosini, 2008; Halupka \& Halupka, 2017). At Helgoland, several passerines begun arriving early after a positive December-March NAOI (Hüppop \& Hüppop, 2003), though NAOI explained only a small part of the variation in spring migration phenology in short- and long-distance migrants (Haest, Hüppop \& Bairlein, 2018). Similarly, in our study, November-March NAOI explained only $13 \%$ of the variation in the timing of Willow Warblers' spring migration (Table 2). November-March NAOI was correlated with the April-May mean of local precipitation in Łeba during our study period (Table S2); we did not include precipitation as a factor in our models because we focused on large-scale climate variables. However, this correlation suggests that the timing of birds' spring migration might be related to winter NAOI indirectly. The direct factor which influences migratory birds' timing might be rather the local rainfall in spring, which is related to winter NAOI. Winter NAOI had a stronger effect on the arrival of short- and mediumdistance migrants in Norway than on long-distance migrants (Forchhammer, Post \& Stenseth, 2002). Long-distance migrants breeding in central and northeastern Europe, including Willow Warbler, migrate farther east and south in Africa than the short- and medium-distance migrants (Cepák et al., 2008; Fransson \& Hall-Karlsson, 2008; Bairlein et al., 2014; Valkama et al., 2014). Our results provide evidence that other large-scale climate indices, which reflect conditions in east and southern Africa, help explain interannual variation in the timing of spring migration in long-distance migrants better than NAOI alone (Table 2).

Of all the climate indices we analysed, the Indian Ocean Dipole (August-October) explained the greatest part (39\%) of interannual variation in the timing of Willow Warblers' spring migration (Table 2, Fig. 4D). This supports the suggestion by Tryjanowski et al. (2013) that the IOD is an important indicator of climate conditions which influence birds breeding in Europe. Red-breasted Flycatchers Ficedula parva arrived early in spring in Białowieża Forest, eastern Poland, in years with a high November-March IOD (Mitrus, Sparks \& Tryjanowski, 2005; Tryjanowski, Stenseth \& Matysioková, 2013). We found a similar relationship between Willow Warblers' arrivals and August-October IOD (Fig. 4D). The timing of the first clutches of 
510 Red-backed Shrikes in central Europe was related to winter IOD, probably through the positive

511 effect of high rainfall in east Africa on their departure condition (Hušek et al., 2008). Female

512 White Storks laid more eggs in western Poland following a high IOD in August and September,

513 but the timing of their spring arrival was not related to the IOD (Tobolka et al., 2018). In the

514 light of these studies, we suggest that a positive August-October IOD, related to high rainfall

515 and temperatures over August-December in east and southeast Africa, has positive effect on the

516 condition of Willow Warblers using these areas for wintering and stopovers, which would

517 facilitate their early arrival in spring at Bukowo. In contrast, a negative winter IOD, indicating

518 low rainfall and temperatures in east and southeast Africa, might be related to the delayed spring

519 arrival of Willow Warblers in Europe, as in other long-distance migrants (Tøttrup et al., 2012).

520 The relationship we found between August-October SOI and the timing of Willow

521 Warblers' spring migration (Table 2, Fig. 4) corresponds with an analogous, though non-

522 significant, relationship between the winter SOI (December-February) and the arrival of long-

523 distance migrants in Oxfordshire, UK (Cotton, 2003). Willow Warblers, and other long-distance

524 migrants, arrived early in Oxfordshire after high mean winter (December-February) temperature

525 anomalies in Africa south of $20^{\circ} \mathrm{N}$ (Cotton, 2003). This could be related to a high winter NAOI,

526 IOD and SOI (Stenseth et al., 2003; Marchant et al., 2006; Schott, Xie \& McCreary, 2009); the

527 three climate indices which were related to this species' arrival. Our results on SOI correspond

528 with those of Miller-Rushing et al. (2008), who showed that several medium-distance migrants

529 arrived early in spring in Massachusetts, USA, after winters with a positive SOI, related to high

530 rainfall in Central America and the Caribbean, where those species winter. The effects of the

531 IOD and SOI on the timing of Willow Warblers' spring passage suggest that a considerable

532 proportion of the population which migrates through the Baltic coasts use east and southeast

533 Africa as stopover and wintering grounds, concurring with migratory connections shown by

534 ringing recoveries (Fransson \& Hall-Karlsson, 2008; Zwarts et al., 2009; Bairlein et al., 2014;

535 Valkama et al., 2014; Maciąg et al., 2017).

536 The relationship we revealed between the Sahel index (November-March) and the timing

537 of Willow Warblers' spring migration at Bukowo (Table 2, Fig. 4G) corresponds with the

538 finding that in the spring of dry years Willow Warblers suffered twice the mortality crossing the

539 Sahara Desert than in wet years (Zwarts et al., 2009). As with Willow Warblers, Barn Swallows

540 arrived in Spain early in the spring after winters with a high SAH in west Africa (Gordo, 2007). 
541 Several passerines, including Willow Warblers, arrived early in spring at Capri, Italy, after wet

542 and hot winters in north Africa and the Sahel (Saino et al., 2007). Female White Storks in

543 western Poland laid more eggs after a high SAH in August and September (Tobolka et al., 2018).

544 In the context of these studies, we suggest that good rainfall in the Sahel during Willow

545 Warblers' stopovers, reflected by a high SAH, probably has a positive effect on their condition

546 and thus facilitates their early arrival at Bukowo in spring.

Carry-over effects of conditions at earlier life stages on Willow Warbler spring migration

The relationship of Willow Warbler spring migration to IOD and SOI in August-October (Table 2, Fig. 4D, E), rather than in November-March when they overwinter in Africa, can be explained in two ways. Firstly, the August-October IOD and SOI influence the ecological conditions which the birds encounter when they arrive in east and southern Africa a few months later. Positive IOD and SOI are related to high rainfall in east and southeast Africa in OctoberDecember (Marchant et al., 2006), which has a positive effect on vegetation in later months (Heino et al., 2018); this would increase the food available for the birds. Secondly, the conditions Willow Warblers encounter during their August-October migration south across east and southeast Africa might have carry-over effects on the next stages of their lives, as in other species. For example, Aloni et al. (2019) showed that high temperatures in SeptemberNovember in north and east Africa, which likely increase insect abundance, when the insectivorous Bonelli's Warbler Phylloscopus orientalis and Lesser Whitethroat Sylvia curruca migrate south through the area, were related to their good body condition and early arrival in spring (February-May) at a stopover site in Eilat, Israel. Analogously, in the European Reed Warbler low rainfall at autumn stopover sites in Spain and Morocco had carry-over effects on their reduced survival and later return to the breeding grounds the following spring (Halupka et al., 2017). The earlier arrival and increased brood size of Redstarts Phoenicurus phoenicurus in the UK was related to high rainfall in the Sahel (Finch et al., 2014), and the high number of eggs laid by White Storks in Poland was related to high positive SAH and IOD in August and September (Tobolka et al., 2018). Early arrival of American Redstarts Setophaga rucilla at highquality wintering sites had a carry-over effect in their early arrival at their breeding sites (McKellar et al., 2013). These findings support our reasoning, and both explanations are likely to be correct for Willow Warblers. 
We suggest that the earliest and the latest spring migrations of Willow Warblers at the

573 Baltic coast reflect the combined effects of the conditions the birds encounter at different life

574

575

576

577

578

579

580

581

582

583

584

585

586

587

588

589

590

591

592

593

594

595

596

597

598

599

600

601

602

stages at multiple locations. The outstandingly early migration of Willow Warblers in 1989 coincided with a positive November-March and April-May NAOI (Figs 4C, 4E), related to an early and warm spring in Europe (Hurrell, 1995) and dry spring locally at Łeba (Table SS2), and with a high positive August-October SOI (Fig. 4F). Such high SOI was related to a strong La Niña anomaly in 1988-1989 (Null, 2019), which brought abundant rainfall to southeast Africa (Stenseth et al., 2003). The outstandingly late migration in 1997 coincided with the lowest August-October IOD of all the years we studied (Fig. 4D), indicating low rainfall in east and southeast Africa (Marchant et al., 2006), and with a negative November-March and April-May NAOI and June-July SCAND index (Figs 4C, 4E). Globally, 2011-2016 were the warmest five years in the past century (Simmons et al., 2017). Willow Warblers arrived at Bukowo early in the spring of 2012-2016 (Fig. 2, Table S1), and high local spring temperatures (Fig. 4A) might be the proximate factor facilitating early arrivals, through the local availability of ample food. However, our results suggest that conditions on the wintering grounds made a decisive contribution to the pattern of Willow Warbler arrivals. The IOD (August-October) in 2012, 2013 and 2016, and SAH (November-March) in 2013 and 2015 were positive (Figs 4D, 4G), indicating good rainfall in east and west Africa. But El Niño in 2015-2016 caused a widespread drought in southern Africa (Heino et al., 2018), reflected by a negative August-October SOI (Fig. 4F). The following April-May 2016 and 2017, Willow Warblers departed from South Africa later than in 2008-2015 (http://sabap2.adu.org.za), as we would expect if drought had weakened their condition. However, Willow Warblers which wintered in western or eastern Africa might have benefitted from high rainfall there, which would probably facilitate the overall early arrival at Bukowo in 2015 and 2016. In contrast, the late spring migration of Willow Warblers at Bukowo in 2017 (Fig. 2), despite a warm April-May at Leba (Fig. 4A), might be related to a combination of low August-October IOD and low June-July SCAND (Figs 4D, 4B). Our results suggest that the conditions the long-distance migrants encounter more than half a year earlier and far away might be more crucial drivers for their early or late arrivals at the breeding grounds in spring than the conditions they experience on spring migration.

\section{Annual Anomaly as an index of phenological events}


603 The shifts in the migration phenology of birds have often been examined using first occurrence 604 dates (e.g. Tryjanowski, Sparks \& Kuźniak, 2002; Cotton, 2003; Mitrus, Sparks \& Tryjanowski, 605 2005; Rubolini et al., 2007; Mason, 2009; Usui, Butchart \& Phillimore, 2017), which might be 606 biased by observer activity, the population size and the presence of outstandingly early 607 individuals (Tryjanowski \& Sparks, 2001; Tryjanowski, Kuźniak \& Sparks, 2005; Gordo, 2007), 608 for "one swallow does not a summer make" (Aristotle 384-322BC, Etica Nicomachea). Other 609 measures used to analyse the timing of passage in birds are the mean dates of migration (e.g. 610 Sokolov et al., 1998; Hüppop \& Hüppop, 2003; Usui, Butchart \& Phillimore, 2017; Haest et al., $6112019)$ and the dates of percentiles of passage, most often of the beginning (5\% or 10\%), median $612(50 \%)$, and end (90\% or 95\%), which reflect different stages of a species' migration (Tøttrup, 613 Thorup \& Rahbek, 2006a; Lehikoinen, Santaharju \& Møller, 2017; Miles et al., 2017; Aloni, 614 Markman \& Ziv, 2019). These are all useful metrics, but none reflects the pattern of the entire 615 migration. AA is one value which is correlated with the dates of all percentiles, but has a smaller 616 variance than the dates of most percentiles, except for $90 \%$ and $95 \%$ (Table S9). We encourage 617 the use of AA as a convenient single measure which reflects the pattern of a species' migration at 618 a location in relation to the many-year average. We calculate AA in a similar manner to a 619 temperature anomaly, which is a departure from a long-term baseline, for example the monthly temperature in a location averaged over a century. Temperature anomalies enable comparisons between locations with different baselines and facilitate studies of climate change (US National Oceanic and Atmospheric Administration, 2019). Analogously, the AA can also be derived from any cumulative data on biodiversity which have a long-term baseline. The Annual Anomaly of bird migration would be easy to derive, update annually and compare, based on existing datasets and continuing activities of bird observatories (e.g. Sokolov et al. 1998; Hüppop and Hüppop 2003; Tøttrup et al. 2006b; Miles et al. 2017; Aloni et al. 2019; Lehikoinen et al. 2019).

\section{CONCLUSIONS}

We provide evidence of the combined effect of large-scale climate indices which operate across Africa and Europe on the phenology of spring migration of a long-distance migrant passerine in Europe. The results support our initial assumption that Willow Warblers caught at Bukowo use wintering grounds which span west, east and southeast Africa. We suggest that a combination of large-scale climate indices, such as NAOI, SAH, IOD and SOI, related to conditions at the non- 
634 breeding grounds, along with indices such as SCAND, related to conditions at the breeding 635 grounds, probably reflect ecological drivers for phenological changes in birds with complex 636 patterns of migrations between continents. Our results emphasise that understanding the effects 637 of climate change on the migration phenology of a migratory bird in one location requires 638 examination of carry-over effects of climatic variation which the different populations 639 experienced at previous life stages in multiple locations. We recommend the use of the Annual 640 Anomaly metric to facilitate studies of long-term phenological responses of birds, and other 641 organisms, to climate change at different locations.

642

\section{ACKNOWLEDGEMENTS}

644 The citizen scientists who collected the data at Operation Baltic's Bukowo ringing station made a 645 decisive contribution to this paper. Eva Poślińska compiled the data for climate indices and helped write R scripts. Michał Redlisiak and Joanna Gruchocka compiled data for the Łeba weather station from http://www.ecad.eu/. The comments from Scott Edwards and three anonymous reviewers helped to improve the manuscript. Joel Avni commented on and edited earlier drafts.

\section{REFERENCES}

Ahola M, Laaksonen T, Sippola K, Eeva T, Rainio K, Lehikoinen E. 2004. Variation in climate warming along the migration route uncouples arrival and breeding dates. Global Change Biology 10:1610-1617. DOI: 10.1111/j.1365-2486.2004.00823.x.

Allan DG, Harrison JA, Herremans M, Navarro R., Underhill LG. 1997. Southern African geography: its relevance to birds. In: Harrison JA, Allan DG, Underhill LG, Herremans M, Tree AJ, Parker V, Brown CJ ed. The Atlas of Southern African Birds. Vol. 1: Non-Passerines. Johannesburg: BirdLife South Africa, 1xv-ci. Aloni I, Markman S, Ziv Y. 2019. Autumn temperatures at African wintering grounds affect body condition of two passerine species during spring migration. PloS One 14:e0217619. DOI: 10.1371/journal.pone.0217619. 
665 Ashok K, Guan Z, Yamagata T. 2003. A look at the relationship between the ENSO and the 666 Indian Ocean Dipole. Journal of the Metheorological Society of Japan 81:41-56.

667 Bairlein F, Dierschke J, Dierschke V, Salewski V, Geiter O, Hüppop K, Köppen U, Fiedler W. 668 2014. Atlas des Vogelzugs: Ringfunde Deutscher Brut- und Gastvögel. Wiebelsheim: AULA669 Verlag.

670 Barshep Y, Erni B, Underhill LG, Altwegg R. 2017. Identifying ecological and life-history 671 drivers of population dynamics of wetland birds in South Africa. Global Ecology and 672 Conservation 12:96-107. DOI: 10.1016/j.gecco.2017.09.001.

673 Barshep Y, Minton C, Underhill LG, Remisiewicz M. 2011. The primary moult of Curlew 674 Sandpipers Calidris ferruginea in north-western Australia shifts according to breeding success. 675 Ardea 99:43-51. DOI: 10.5253/078.099.0106.

676 Bartoń K. 2019. Package “MuMIn”. Multi-Model Inference. Available at https://cran.r677 project.org/web/packages/MuMIn/MuMIn.pdf. (accessed November 20, 2019).

678 Bensch S, Bengtsson G, Åkesson S. 2006. Patterns of stable isotope signatures in Willow

679 Warbler Phylloscopus trochilus feathers collected in Africa. Journal of Animal Ecology 37:323680330.

681 Bensch S, Grahn M, Müller N, Gay L, Åkesson S. 2009. Genetic, morphological, and feather 682 isotope variation of migratory willow warblers show gradual divergence in a ring. Molecular 683 Ecology 18:3087-3096. DOI: 10.1111/j.1365-294X.2009.04210.x.

684 Bensch S, Liedvogel M, Åkesson S. 2011. The genetics of migration on the move. Trends in 685 Ecology and Evolution 26:561-569. DOI: 10.1016/j.tree.2011.07.009.

686 Black E. 2005. The relationship between Indian Ocean sea-surface temperature and East African 687 rainfall sea-surface temperature and East African rainfall. Philosophical Transactions of the 688 Royal Society A: Mathematical, Physical \& Engineering Sciences 363:43-47. DOI: $68910.1098 /$ rsta.2004.1474.

690 Bueh C, Nakamura H. 2007. Scandinavian pattern and its climatic impact. Quarterly Journal of 691 the Royal Meteorological Society 133:2117-2131. DOI: 10.1002/qj.

692 Busse P, Meissner W. 2015. Bird Ringing Station Manual. Warsaw/Berlin: De Gruyter Open 693 Ltd. 
694 Bussière EMS, Underhill LG, Altwegg R. 2015. Patterns of bird migration phenology in South 695 Africa suggest northern hemisphere climate as the most consistent driver of change. Global 696 Change Biology 21:2179-2190. DOI: 10.1111/gcb.12857.

697 Cepák J, Klwaňa P, Škopek J, Schröpfer L, Jelínek M, Hořák D, Formánek J, Zárybnický J. 698 2008. Atlas Migrace Ptákû České Republiky a Slovenska. Prague: Aventinum.

699 Conklin JR, Battley PF. 2012. Carry-over effects and compensation: Late arrival on non-

700 breeding grounds affects wing moult but not plumage or schedules of departing Bar-tailed

701 Godwits Limosa lapponica baueri. Journal of Avian Biology 43:252-263. DOI: 10.1111/j.1600702 048X.2012.05606.x.

703 Cotton PA. 2003. Avian migration phenology and global climate change. Proceedings of the

704 National Academy of Sciences 100:12219-12222.

705 Cowpertwait PSP, Metcalfe AV. 2009. Introductory Time Series with R. Dordrecht, Heidelberg:

706 Springer.

707 Cramp S, Brooks DJ. 1992. The Birds of the Western Palearctic. Handbook of the Birds of 708 Europe, the Middle East and North Africa. Vol. VI: Warblers. Oxford: Oxford University Press.

709 Crawford RJM, Siegfried RW, Shannon LV, Villacastin-Herrero CA, Underhill LG. 1990.

710 Environmental influences on marine biota off Southern Africa. South African Journal of Science $71186: 330-339$.

712 Crawley MJ. 2013. The R Book. Chichester, England: John Wiley \& Sons.

713 Dean WRJ. 2005. Willow Warbler Phylloscopus trochilus. In: Hockey P.A.R., Dean W.R.J. RPG 714 ed. Roberts' Birds of Southern Africa, VIIth ed. Cape Town: Trustees of the John Voelcker Bird 715 Book Fund, 807-808.

716 Demongin L. 2016. Identification Guide to Birds in the Hand. Beauregard-Vendon: Laurent 717 Demongin.

718 Dormann CF, Elith J, Bacher S, Buchmann C, Carl G, Carr G, Garc JR, Gruber B, Lafourcade B, 719 Leit PJ, Tamara M, Mcclean C, Osborne PE, Der BS, Skidmore AK, Zurell D, Lautenbach S. 720 2013. Collinearity : a review of methods to deal with it and a simulation study evaluating their 721 performance. Ecography 36:27-46. DOI: 10.1111/j.1600-0587.2012.07348.x.

722 Elkins N. 1988. Weather and bird behaviour. 2nd edition. London: T \& A D Poyser.

723 Finch T, Pearce-Higgins JW, Leech DI, Evans KL. 2014. Carry-over effects from passage

724 regions are more important than breeding climate in determining the breeding phenology and 
725 performance of three avian migrants of conservation concern. Biodiversity and Conservation 726 23:2427-2444. DOI: 10.1007/s10531-014-0731-5.

727 Forchhammer MC, Post E, Stenseth NCHR. 2002. North Atlantic Oscillation timing of long- and 728 short-distance migration. Journal of Animal Ecology 71:1002-1014.

729 Fox J, Friendly M, Monette G. 2007. Visual hypothesis tests in multivariate linear models: The 730 heplots package for R. Directions in Statistical Computing.

731 Fox J, Weisberg S. 2011. An R Companion to Applied Regression. 2nd edition. Sage: Thousand 732 Oaks CA.

733 Franke GR. 2010. Multicollinearity. In: Sheth J, Malhotra N eds. Wiley International

734 Encyclopedia of Marketing. Wiley,. DOI: doi:10.1002/9781444316568.wiem02066.

735 Fransson T, Hall-Karlsson S. 2008. Svensk Ringmärkningsatlas. Vol. 3. Stockholm:

736 Naturhistoriska riksmuseet \& Sveriges Ornitologiska Forening.

737 Frost J. 2019. Regression Analysis. An Intuitive Guide for Using and Interpreting Linear Models.

738 1st ed. Jim Frost. Available at: statisticsbyjim.com

739 González-Prieto AM, Hobson KA. 2013. Environmental conditions on wintering grounds and

740 during migration influence spring nutritional condition and arrival phenology of Neotropical

741 migrants at a northern stopover site. Journal of Ornithology 154:1067-1078. DOI:

742 10.1007/s10336-013-0975-y.

743 Gordo O. 2007. Why are bird migration dates shifting? A review of weather and climate effects

744 on avian migratory phenology. Climate Research 35:37-58. DOI: 10.3354/cr00713.

745 Gordo O, Barriocanal C, Robson D. 2011. Ecological Impacts of the North Atlantic Oscillation

746 (NAO) in Mediterranean Ecosystems. In: Vicente-Serrano SM, Trigo RM eds. Hydrological,

747 Socioeconomic and Ecological Impacts of the North Atlantic Oscillation in the Mediterranean

748 Region. Springer Science+Business Media B.V., 153-170.

749 Grimm A, Weiß BM, Kulik L, Mihoub J, Mundry R, Brueckmann T, Thomsen R, Widdig A,

750 Ulrich K. 2015. Earlier breeding, lower success: does the spatial scale of climatic conditions

751 matter in a migratory passerine bird?:5722-5734. DOI: 10.1002/ece3.1824.

752 Haest B, Hüppop O, Bairlein F. 2018. Challenging a 15-year-old claim: The North Atlantic

753 Oscillation index as a predictor of spring migration phenology of birds. Global Change Biology $754 \quad 24: 1523-1537$. 
755 Haest B, Hüppop O, van de Pol M, Bairlein F. 2019. Autumn bird migration phenology: A pot

756 pourri of wind, precipitation, and temperature effects. Global Change Biology:gcb.14746. DOI:

$757 \quad 10.1111 /$ gcb.14746.

758 Halkka A, Lehikoinen A, Velmala W. 2011. Do long-distance migrants use temperature

759 variations along the migration route in Europe to adjust the timing of their spring arrival? Boreal

760 Environment Research 16 (suppl. B):35-48.

761 Halupka L, Halupka K. 2017. The effect of climate change on the duration of avian breeding

762 seasons : a meta-analysis. Proceedings of the Royal Society B: Biological Sciences

763 284:20171710. DOI: http://dx.doi.org/10.1098/rspb.2017.1710.

764 Halupka L, Wierucka K, Sztwiertnia H, Klimczuk E. 2017. Conditions at autumn stopover sites

765 affect survival of a migratory passerine. Journal of Ornithology 158:979-988. DOI:

$76610.1007 / \mathrm{s} 10336-017-1472-5$.

767 Hayhow DB, Conway G, Eaton MA, Grice PV, Hall C, Holt CA, Kuepfer A, Noble DG, Oppel

768 S, Risely K, Stringer C, Stroud DA, Wilkinson N, Wotton S. 2014. The State of the UK's Birds.

769 Sandy, Bedfordshire: Royal Society for the Protection of Birds.

770 Hedlund JSU, Jakobsson S, Kullberg C, Fransson T. 2014. Long-term phenological shifts and

771 intra-specific differences in migratory change in the Willow Warbler Phylloscopus trochilus.

772 Journal of Avian Biology 45:1-10. DOI: 10.1111/jav.00484.

773 Heino M, Puma MJ, Ward PJ, Kummu M, Gerten D, Heck V, Siebert S. 2018. Two-thirds of

774 global cropland area impacted by climate oscillations. Nature Communications 9:1-10. DOI:

775 10.1038/s41467-017-02071-5.

776 Herremans M. 1999. Willow Warbler Phylloscopus trochilus. In: Harrison JA, Allan DG,

777 Underhill LG, Herremans M, Tree AJ, Parker V, Brown CJ eds. The Atlas of Southern African

778 Birds. Vol. 2: Passerines. Johannesburg: BirdLife South Africa, 254-255.

779 Hüppop O, Hüppop K. 2003. North Atlantic Oscillation and timing of spring migration in birds.

780 Proceedings of the Royal Society B: Biological Sciences 270:233-240. DOI:

781 10.1098/rspb.2002.2236.

782 Hurrell JW. 1995. Decadal trends in the North Atlantic Oscillation: Regional temperatures and 783 precipitation. Science 269:676-679. DOI: 10.1126/science.269.5224.676. 
784 Hušek J, Adamík P, Cepák J, Tryjanowski P. 2008. The influence of climate and population size 785 on the distribution of breeding dates in the Red-backed Shrike (Lanius collurio). Annales 786 Zoologici Fennici 46:439-450.

787 Jonzén N, Ergon T, Lindén A, Stenseth NC. 2007. Bird migration and climate: The general 788 picture and beyond. Climate Research 35:177-180. DOI: 10.3354/cr00724.

789 Jørgensen PS, Böhning-Gaese K, Thorup K, Tøttrup AP, Chylarecki P, Jiguet F, Lehikoinen A, 790 Noble DG, Reif J, Schmid H, van Turnhout C, Burfield IJ, Foppen R, Voříšek P, van Strien A, 791 Gregory RD, Rahbek C. 2016. Continent-scale global change attribution in European birds 792 combining annual and decadal time scales. Global Change Biology 22:530-543. DOI: $79310.1111 /$ gcb.13097.

794 Katti M, Price T. 1999. Annual variation in fat storage by a migrant warbler overwintering in the 795 Indian tropics. Journal of Animal Ecology 68:815-823. DOI: 10.1046/j.1365-

796 2656.1999.00331.x.

797 Kokko H, Gunnarson T, Morrel LJ, Gill JA. 2006. Why do female migratory birds arrive later 798 than males? Journal of Animal Ecology 75:1293-1303.

799 Lehikoinen A, Lindén A, Karlsson M, Andersson A, Crewe TL, Dunn EH, Gregory G, Karlsson

800 L, Kristiansen V, Mackenzie S, Newman S, Erik J, Sharpe C, Sokolov L V., Steinholtz Å., 801 Stervander M, Tirri I-S, Tjørnløv RS. 2019. Phenology of the avian spring migratory passage in 802 Europe and North America : Asymmetric advancement in time and increase in duration.

803 Ecological Indicators 101:985-991. DOI: 10.1016/j.ecolind.2019.01.083.

804 Lehikoinen A, Santaharju J, Møller AP. 2017. Sex-specific timing of autumn migration in birds 805 Sex-specific timing of autumn migration in birds: the role of sexual size dimorphism, migration 806 distance and differences in breeding investment. Ornis Fennica 94:53-65.

807 Lerche-Jørgensen M, Willemoes M, Tøttrup AP, Snell Scotchburn KR. 2017. No apparent gain 808 from continuing migration for more than 3000 kilometres : willow warblers breeding in Denmark 809 winter across the entire northern Savannah as revealed by geolocators. Movement Ecology 5: 17. 810 DOI: $10.1186 / \mathrm{s} 40462-017-0109-x$.

811 Lingbeek BJ, Higgins CL, Muir JP, Kattes DH, Schwertner TW. 2017. Arthropod diversity and 812 assemblage structure response to deforestation and desertification in the Sahel of western 813 Senegal. Global Ecology and Conservation 11:165-176. DOI: 10.1016/j.gecco.2017.06.004. 
814 Ljung GM, Box GEP. 1978. On a measure of lack of fit in time series models. Biometrika $815 \quad 65: 297-303$.

816 Maciąg T, Remisiewicz, M. Nowakowski JK, Redlisiak M, Rosińska K, Stępniewski K, 817 Stępniewska K, Szulc J. 2017.Website of the Bird Migration Research Station. Available at 818 http://www.sbwp.ug.edu.pl/badania/monitoringwyniki/ (accessed February 7, 2019).

819 MacMynowski DP, Root TL. 2007. Climate and the complexity of migratory phenology: sexes, 820 migratory distance, and arrival distributions. International Journal of Biometeorology 51:361821 373. DOI: 10.1007/s00484-006-0084-1.

822 Marchant R, Mumbi C, Behera S, Yamagata T. 2006. The Indian Ocean dipole - the unsung 823 driver of climatic variability in East Africa. African Journal of Ecology 45:4-16.

824 Marchowski D, Jankowiak Ł, Wysocki D, Ławicki Ł, Girjatowicz J. 2017. Ducks change 825 wintering patterns due to changing climate in the important wintering waters of the Odra River 826 Estuary. PeerJ 5:e3604. DOI: 10.7717/peerj.3604.

827 Mason CF. 2009. Long-term trends in the arrival dates of spring migrants. Bird Study 42:182828 189. DOI: $10.1080 / 00063659509477167$.

829 McKellar AE, Marra PP, Hannon SJ, Studds CE, Ratcliffe LM. 2013. Winter rainfall predicts 830 phenology in widely separated populations of a migrant songbird. Oecologia 172. DOI:

831 10.1007/s00442-012-2520-8.

832 Miles WTS, Bolton M, Davis P, Dennis R, Broad R, Robertson I, Riddiford NJ, Harvey PV, 833 Riddington R, Shaw DN, Parnaby D, Reid JM. 2017. Quantifying full phenological event 834 distributions reveals simultaneous advances, temporal stability and delays in spring and autumn 835 migration timing in long-distance migratory birds. Global Change Biology 23:1400-1414. DOI: $836 \quad 10.1111 /$ gcb.13486.

837 Miller-Rushing AJ, Lloyd-Evans TL, Primack RB, Satzinger P. 2008. Bird migration times, 838 climate change, and changing population sizes. Global Change Biology 14:1959-1972. DOI: 839 doi:10.1111/j.1365-2486.2008.01619.x.

840 Mitrus C, Sparks TH, Tryjanowski P. 2005. First evidence of phenological change in a 841 transcontinental migrant overwintering in the Indian sub-continent: the Red-breasted Flycatcher 842 Ficedula parva. Ornis Fennica 82:13-19. 
843 Møller AP. 2002. North Atlantic Oscillation (NAO) effects of climate on the relative importance

844 of first and second clutches in a migratory passerine bird. Journal of Animal Ecology 71:201845210.

846 Munemoto M, Tachibana Y. 2012. The recent trend of increasing precipitation in Sahel and the 847 associated inter-hemispheric dipole of global SST. International Journal of Climatology

848 1353:1346-1353. DOI: 10.1002/joc.2356.

849 Newton I. 2010. Bird Migration. London: Collins.

850 van Noordwijk AJ, Rainio K, Laaksonen T, Ahola M, Vähätalo A V., Lehikoinen E, Tøttrup AP, 851 Lehikoinen E, Coppack T, Jarjour C, Frei B, Elliott KH, Gill JA, Lehikoinen A, Santaharju J, 852 Møller AP, Mills AM, Spottiswoode CN, Tøttrup AP, Coppack T. 2006. The earlier bird. Nature 853 422:107-114. DOI: 10.1111/j.0908-8857.2006.03740.x.

854 Nowakowski JK, Muś K, Stępniewski K, Manikowska-Ślepowrońska B, Szulc J. 2012.

855 Internetowa Baza Danych Programu Badawczego “Akcja Bałtycka”. Available at

856 http://akbalt.ug.edu.pl/kssop (accessed February 6, 2019).

857 Nowakowski JK, Remisiewicz M, Keller M, Busse P, Rowiński P. 2005. Synchronisation of the 858 autumn mass migration of passerines: a case of Robins Erithacus rubecula. Acta Ornithologica $85940: 103-115$.

860 Null J. 2019.El Niño and La Niña years and intensities. Available at

861 https://ggweather.com/enso/oni.htm (accessed July 22, 2019).

862 Ockendon N, Leech D, Pearce-Higgins JW. 2013. Climatic effects on breeding grounds are more 863 important drivers of breeding phenology in migrant birds than carry-over effects from wintering 864 grounds. Biology Letters 9:20130669. DOI: 10.1098/rsbl.2013.0669.

865 Ouwehand J, Both C. 2017. African departure rather than migration speed determines variation 866 in spring arrival in Pied Flycatchers. Journal of Animal Ecology 86:88-97. DOI: 10.1111/13658672656.12599.

868 Palm V, Leito A, Truu J, Tomingas O. 2009. The spring timing of arrival of migratory birds:

869 Dependence on climate variables and migration route. Ornis Fennica 86:97-108. DOI: 870 vellop@ut.ee.

871 Pasinelli G, Schaub M, Häfliger G, Frey M, Jakober H, Müller M, Stauber W, Tryjanowski P, 872 Zollinger JL, Jenni L. 2011. Impact of density and environmental factors on population 
873 fluctuations in a migratory passerine. Journal of Animal Ecology 80:225-234. DOI:

874 10.1111/j.1365-2656.2010.01754.x.

875 Peach W, Baillie S, Underhill LG. 1991. Survival of British sedge warblers Acrocephalus

876 schoenobaenus in relation to West African rainfall. Ibis 133:300-305.

877 Peñuelas J. 2009. Phenology feedbacks on climate change. Science 324:887-888. DOI:

$878 \quad 10.1126 /$ science. 1173004.

879 R Core Team. 2018.R: a language and environment for statistical computing. R Foundation for

880 Statistical Computing. Vienna, Austria. Available at https://www.r-project.org

881 Rainio K, Laaksonen T, Ahola M, Vähätalo AV, Lehikoinen E. 2006. Climatic responses in

882 spring migration of boreal and arctic birds in relation to wintering area and taxonomy. Journal of

883 Avian Biology 37:507-515. DOI: 10.1111/j.0908-8857.2006.03740.x.

884 Redlisiak M, Remisiewicz M, Nowakowski JK. 2018. Long-term changes in migration timing of

885 Song Thrush Turdus philomelos at the southern Baltic coast in response to temperatures on route

886 and at breeding grounds. International Journal of Biometeorology 62:1595-1605 .DOI:

887 10.1007/s00484-018-1559-6.

888 Remisiewicz M, Bernitz Z, Bernitz H, Burman MS, Raijmakers J, Raijmakers J, Underhill LG,

889 Rostkowska A, Barshep Y, Soloviev SA, Siwek I. 2019. Contrasting strategies for wing-moult

890 and pre-migratory fuelling in western and eastern populations of Common Whitethroat Sylvia

891 communis. Ibis.161: 824-838. DOI: 10.1111/ibi.12686.

892 Rubolini D, Møller AP, Rainio K, Lehikoinen E. 2007. Intraspecific consistency and geographic

893 variability in temporal trends of spring migration phenology among European bird species.

894 Climate Research 35:135-146. DOI: 10.3354/cr00720.

895 Saino N, Ambrosini R. 2008. Climatic connectivity between Africa and Europe may serve as a

896 basis for phenotypic adjustment of migration schedules of trans-Saharan migratory birds. Global

897 Change Biology 14:250-263. DOI: 10.1111/j.1365-2486.2007.01488.x.

898 Saino N, Rubolini D, Jonzén N, Ergon T, Montemaggiori A, Stenseth NC, Spina F. 2007.

899 Temperature and rainfall anomalies in Africa predict timing of spring migration in trans-Saharan

900 migratory birds. Climate Research 35:123-134. DOI: 10.3354/cr00719.

901 Saji NH, Vinayachandran PN. 1999. A dipole mode in the tropical Indian Ocean. Nature

$902 \quad 401: 360-364$. 
903 Salewski V, Altwegg R, Erni B, Falk KH, Bairlein F, Leisler B. 2004. Moult of three Palaearctic

904 migrants in their West African winter quarters. Journal of Ornithology 145:109-116. DOI:

905 10.1007/s10336-004-0020-2.

906 Schott FA, Xie S-P, McCreary JPJ. 2009. Indian Ocean circulation and climate variability.

907 Reviews of Geophysics 47:1-46. DOI: 10.1029/2007RG000245.

908 Simmons AJ, Berrisford P, Dee DP, Hersbach H, Hirahara S, Thépaut JN. 2017. A reassessment

909 of temperature variations and trends from global reanalyses and monthly surface climatological

910 datasets. Quarterly Journal of the Royal Meteorological Society 143:101-119.

911 Simmons RE, Kolberg H, Braby R, Erni B. 2015. Declines in migrant shorebird populations

912 from a winter-quarter perspective. Conservation Biology 29:877-887. DOI: 10.1111/cobi.12493.

913 Sokolov LV, Markovets MY, Shapoval AP, Morozov YG. 1998. Long-term trends in the timing

914 of spring migration of passerines on the Courish Spit of the Baltic Sea. Avian Ecology and

915 Behaviour 1:1-21.

916 Sparks TH, Tryjanowski P. 2005. The detection of climate impacts: Some methodological

917 considerations. International Journal of Climatology 25:271-277. DOI: 10.1002/joc.1136.

918 Stenseth NC, Ottersen G, Hurrell JW, Mysterud A, Lima M, Chan K, Yoccoz NG, Bjørn A.

919 2003. Studying climate effects on ecology through the use of climate indices: the North Atlantic

920 Oscillation, El Niño Southern Oscillation and beyond. Proceedings of the Royal Society B:

921 Biological Sciences:2087-2096. DOI: 10.1098/rspb.2003.2415.

922 Studds CE, Marra PP. 2011. Rainfall-induced changes in food availability modify the spring

923 departure programme of a migratory bird. Proceedings of the Royal Society B: Biological

924 Sciences 278:3437-3443. DOI: 10.1098/rspb.2011.0332.

925 Svensson L. 1992. Identification Guide to European Passerines. L. Svensson. Stockholm.

926 Thorup K, Araújo MB, Rahbek C, Vega ML, Dasari HP, Willemoes M, Klaassen RHG,

927 Strandberg R, Tøttrup AP, Wikelski M. 2017. Resource tracking within and across continents in

928 long-distance bird migrants. Science Advances 3:e1601360. DOI: 10.1126/sciadv.1601360.

929 Tobolka M, Dylewski L, Wozna JT, Zolnierowicz KM. 2018. How weather conditions in non-

930 breeding and breeding grounds affect the phenology and breeding abilities of White Storks.

931 Science of the Total Environment 636:512-518. DOI: 10.1016/j.scitotenv.2018.04.253.

932 Tomiałojć L, Stawarczyk T. 2003. Awifauna Polski: rozmieszczenie, liczebność i zmiany.

933 Wrocław: PTPP “pro Natura.” 
934 Tomotani BM, van der Jeugd H, Gienapp P, de la Hera I, Pilzecker J, Teichmann C, Visser ME.

935 2018. Climate change leads to differential shifts in the timing of annual cycle stages in a

936 migratory bird. Global Change Biology 24:823-835. DOI: 10.1111/gcb.14006.

937 Tøttrup AP, Klaassen RHG, Kristensen MW, Strandberg R, Vardanis Y, Lindström Å, Rahbek

938 C, Alerstam T, Thorup K. 2012. Drought in Africa caused delayed arrival of European

939 songbirds. Science 338:1307. DOI: 10.1126/science.1227548.

940 Tøttrup AP, Thorup K, Rahbek C. 2006a. Patterns of change in timing of spring migration in

941 North European songbird populations. Journal of Avian Biology 37:84-92. DOI:

942 10.1111/j.2006.0908-8857.03391.x.

943 Tøttrup AP, Thorup K, Rahbek C. 2006b. Changes in timing of autumn migration in North

944 European songbird populations. Ardea 94:527-536. DOI: 10.1111/j.2006.0908-8857.03391.x.

945 Tryjanowski P, Kuźniak S, Sparks TH. 2005. What affects the magnitude of change in first

946 arrival dates of migrant birds? Journal of Ornithology 146:200-205. DOI: 10.1007/s10336-005-

$947 \quad 0079-4$.

948 Tryjanowski P, Sparks TH. 2001. Is the detection of the first arrival date of migrating birds

949 influenced by population size? A case study of the Red-backed Shrike Lanius collurio.

950 International Journal of Biometeorology 45:217-219. DOI: 10.1007/s00484-001-0112-0.

951 Tryjanowski P, Sparks TH, Kuźniak S. 2002. Earlier arrival date of some farm land migrants in 952 western Poland. Ibis 144:62-68.

953 Tryjanowski P, Stenseth NC, Matysioková B. 2013. The Indian Ocean Dipole as an indicator of 954 climatic conditions affecting European birds. Climate Research 57:45-49. DOI:

$95510.3354 / \mathrm{cr} 01162$.

956 US National Oceanic and Atmospheric Administration. 2019.Anomalies vs. Temperature.

957 Available at https://www.ncdc.noaa.gov/monitoring-references/dyk/anomalies-vs-temperature

958 (accessed July 22, 2019).

959 Usui T, Butchart SHM, Phillimore AB. 2017. Temporal shifts and temperature sensitivity of

960 avian spring migratory phenology: a phylogenetic meta-analysis. Journal of Animal Ecology

961 86:250-261. DOI: 10.1111/1365-2656.12612.

962 Vähätalo AV, Rainio K, Lehikoinen A, Lehikoinen E. 2004. Spring arrival of birds depends on 963 the North Atlantic Oscillation. Journal of Avian Biology 35:210-216. 
964 Valkama J, Saurola P, Lehikoinen A, Lehikoinen E, Piha M, Sola P, Velmala W. 2014. Suomen 965 Rengastysatlas II. [The Finnish Bird ringing Atlas], Vol. II. Helsinki: Finnish Museum of 966 Natural History and Ministry of Environment.

967 Venables WN, Ripley BD. 2002. Modern Applied Statistics with S. Fourth Edition. New York: 968 Springer.

969 Vose RS, Easterling DR, Gleason B. 2005. Maximum and minimum temperature trends for the 970 globe: an update through 2004. Geophysical. Research Letters:L23822.

971 Walther G-R, Post E, Convey P, Menzel A, Parmesan C, Beebee TJC, Fromentin J-M, Hoegh972 Guldberg, O. Bairlein F. 2002. Ecological responses to recent climate change. Nature:389-395.

973 Wood EM, Kellermann JL. 2015. Phenological synchrony and bird migration. Changing climate 974 and seasonal resources in North America. Cooper Ornithological Society ed. Boca Raton, 975 London, New York: Taylor \& Francis.

976 Zaifman J, Shan D, Ay A, Jimenez AG. 2017. Shifts in bird migration timing in North American 977 long-distance and short-distance migrants are associated with climate change. International 978 Journal of Zoology, Volume 2017, Article ID 6025646. DOI: 10.1155/2017/6025646.

979 Zduniak P, Yosef R, Sparks TH, Smit H, Tryjanowski P. 2010. Rapid advances in the timing of 980 the spring passage migration through Israel of the Steppe Eagle Aquila nipalensis. Climate 981 Research 42:217-222. DOI: 10.3354/cr00900.

982 Zwarts L, Bijlsma RG, van der Kamp J, Wymenga E. 2009. Living on the Edge: Wetlands and 983 Birds in a Changing Sahel. Zeist: KNNV Publishing. 
Figure 1

The hypothetical pattern of the influences of the climate variables we used in the study in relation to the Willow Warbler range $(A)$ and life cycle $(B)$.

(A) Approximate migration routes and migratory divides (after Bensch et al., 2009) for the two subspecies that pass through Bukowo, and centres of the large-scale climate anomalies and regions they influence. Abbreviations as in Table 1. (B) Four main periods in an annual cycle of Willow Warbler. This figure ("Willow Warbler and climate indices") is a derivative of " Phylloscopus trochilus Range Map.png " by Keith W. Larson, licenced under CC-BY-SA-3.0, and is licenced under CC-BY-SA-3.0 by Magdalena Remisiewicz.
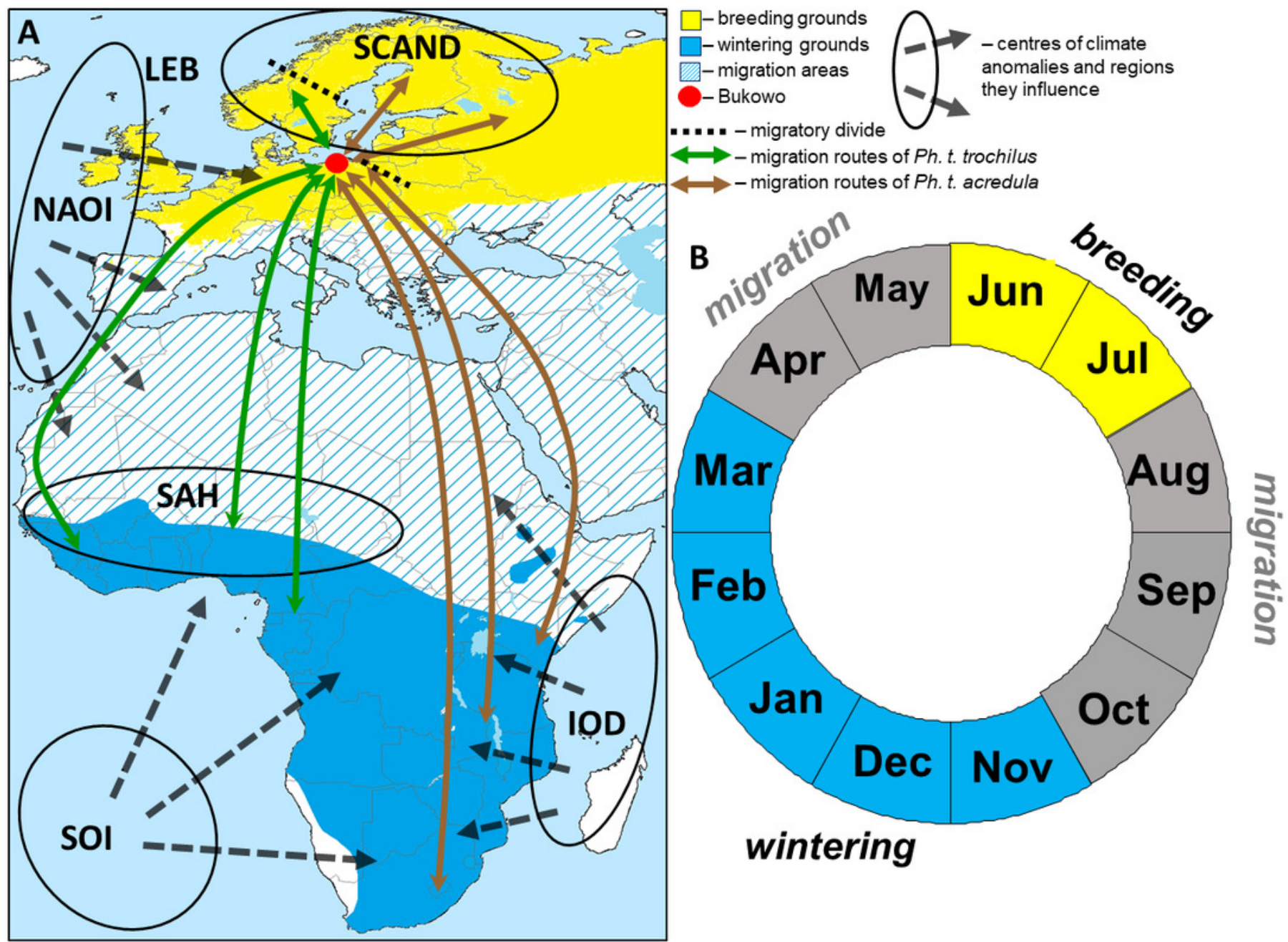
Figure 2

Visual representation of the Annual Anomaly (AA).

(A) Spring migration in 1997 in relation to the regression line of overall spring migration during 1982-2017; (B) Spring migration in 1989 in relation to the regression line of overall spring migration during 1982-2017 (Fig. 3B, Table S1). 

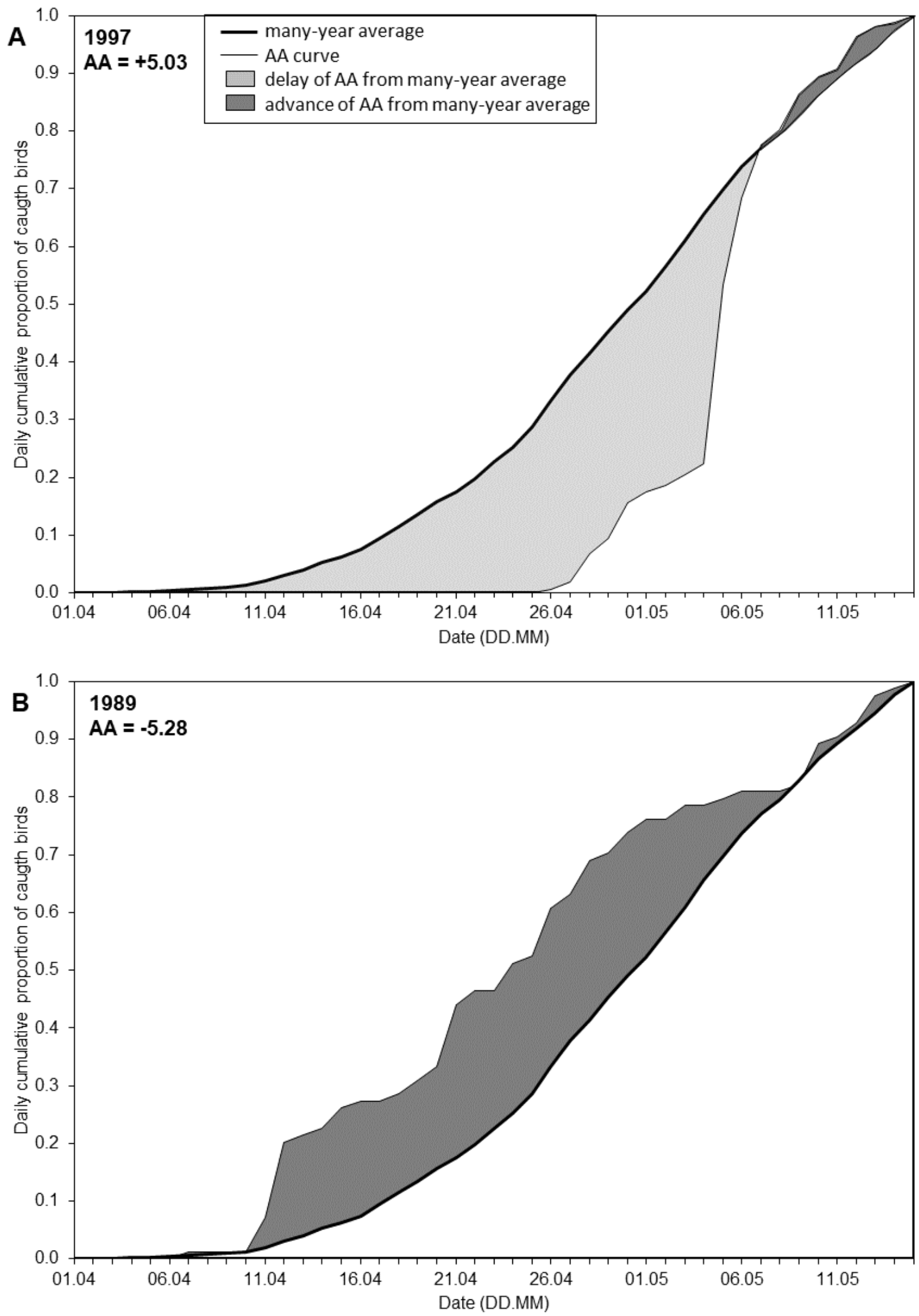
Figure 3

Trends in migration dates of $10 \%, 50 \%$ and $90 \%$ and the Annual Anomaly (AA) for Willow Warbler spring migration at Bukowo, Poland, over 1982-2017.

(A) Dates of the beginning (10\%), median (50\%) and end (90\%) of migration. (B) Annual Anomaly (AA) trends by linear regression. More statistics for regression equations in Table S4. 

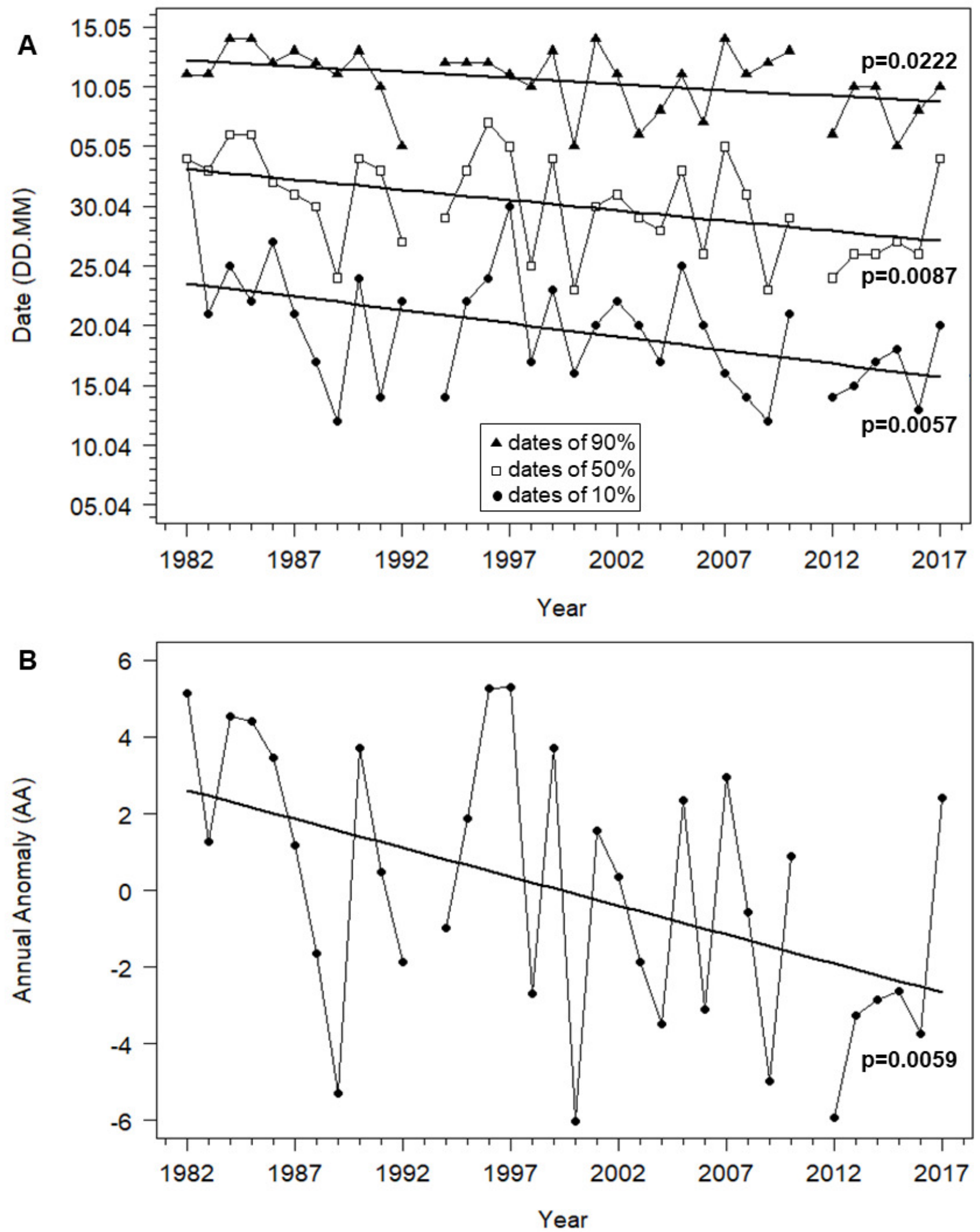


\section{Figure 4}

Annual Anomaly (AA) of Willow Warblers' spring migration at Bukowo in 1982-2017 against the climate indices in the best model (Table 2).

All variables presented as standardised values. The numbers alongside the black circles are the last two digits of the year. $p<0.05$ marked in bold face, $0.05<p<0.1$ in italics. (A) AA against mean of local temperature in Łeba in April-May. (B) AA against mean Scandinavian Index in June-July. (C) AA against mean North Atlantic Oscillation Index in April-May. (D) AA against mean Indian Ocean Dipole in August-October. (E) AA against mean North Atlantic Oscillation Index in November-March. (F) AA against mean Southern Oscillation Index in August-October. (G) AA against mean Sahel Precipitation Anomaly in August-October. 

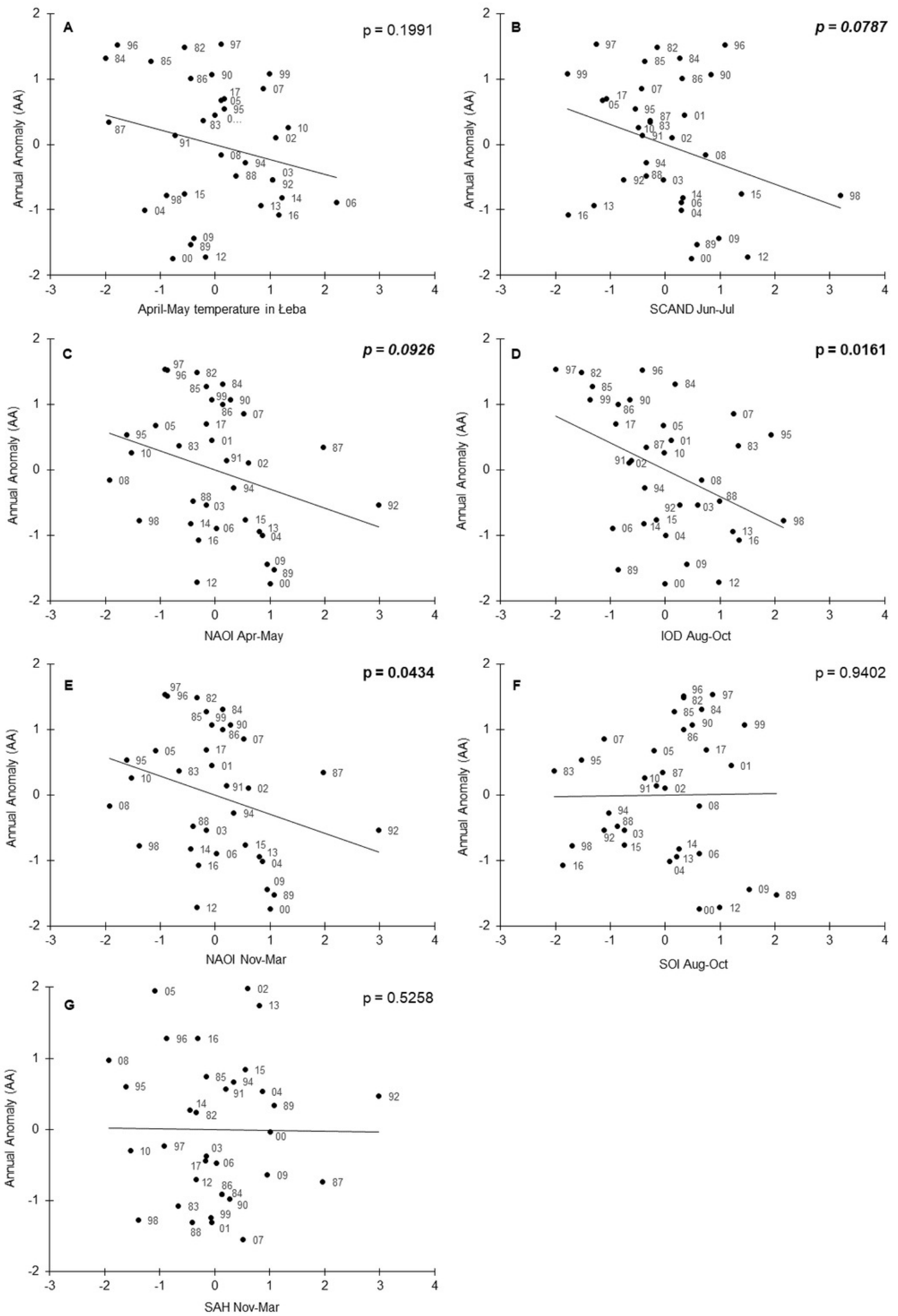


\section{Table $\mathbf{1}$ (on next page)}

Fourteen explanatory variables and the response variable (AA), used in modelling of Willow Warbler spring migration (1 April-15 May) in 1982-2017 at Bukowo ringing station (N Poland).

$\chi^{2}, P$ - results of the Ljung-Box portmanteau for a lag up to 10 years used to test the null hypothesis of a lack of autocorrelations in each data series. The weather indices are presented in reverse order of life stages during the year preceding their April-May migration through Bukowo. 


\begin{tabular}{lllrl}
\hline No & $\begin{array}{l}\text { Abbreviations } \\
\text { used in the text }\end{array}$ & Variable & $\chi^{2}$ & $P$ \\
\hline 1 & Year & Year, as the year number from 1982 = Year 1 & - & - \\
2 & LEB T Apr-May & Apr-May mean of the daily means of temperatures in Leba & 12.20 & 0.27 \\
3 & NAOI Apr-May & Apr-May mean of the Northern Atlantic Oscillation Index & 12.59 & 0.25 \\
4 & SCAN Apr-May & Apr-May mean of the Scandinavian Pattern Index & 10.11 & 0.43 \\
5 & NAOI Nov-Mar & Nov-Mar mean of the Northern Atlantic Oscillation Index & 3.21 & 0.98 \\
6 & SAH Nov-Mar & Nov-Mar mean of the Sahel Precipitation Anomaly & 13.39 & 0.20 \\
7 & IOD Nov-Mar & Nov-Mar mean of the Indian Ocean Dipole & 7.19 & 0.71 \\
8 & SOI Nov-Mar & Nov-Mar mean of the Southern Oscillation Index & 1.33 & 0.99 \\
9 & NAOI Aug-Oct & Aug-Oct mean of the Northern Atlantic Oscillation Index & 13.79 & 0.18 \\
10 & SAH Aug-Oct & Aug-Oct mean of the Sahel Precipitation Anomaly & 7.68 & 0.66 \\
11 & IOD Aug-Oct & Aug-Oct mean of the Indian Ocean Dipole & 11.33 & 0.33 \\
12 & SOI Aug-Oct & Aug-Oct mean of the Southern Oscillation Index & 6.23 & 0.80 \\
13 & NAOI Jun-Jul & Jun-Jul mean of the Northern Atlantic Oscillation Index & 2.65 & 0.99 \\
14 & SCAND Jun-Jul & Jun-Jul mean of the Scandinavian Index & 14.14 & 0.17 \\
\hline 15 & AA & Annual Anomaly (AA) in spring at Bukowo & 9.88 & 0.45 \\
\hline
\end{tabular}




\section{Table 2 (on next page)}

Pearson's correlation coefficients between the 13 climate indices and the year in 1982-2017 used in multiple regression models.

Significant correlations $(P<0.05)$ marked in bold face. VIF - variance inflation factors in the full model with all variables included. Abbreviations in Table 1. 
1

\begin{tabular}{lllllll}
\hline $\begin{array}{l}\text { Explanatory } \\
\text { variable }\end{array}$ & Estimate & SE & $t$ & $P$ & VIF & $R^{2}$ \\
\hline LEB T Apr-May & -0.416 & 0.124 & -3.34 & 0.002 & 1.23 & 0.29 \\
NAOI Apr-May & -0.371 & 0.118 & -3.14 & 0.004 & 1.11 & 0.27 \\
NAOI Nov-Mar & -0.241 & 0.119 & -2.03 & 0.052 & 1.12 & 0.13 \\
SAH Nov-Mar & -0.242 & 0.116 & -2.08 & 0.047 & 1.08 & 0.14 \\
IOD Aug-Oct & -0.565 & 0.153 & -3.07 & $<0.001$ & 1.86 & 0.34 \\
SOI Aug-Oct & -0.385 & 0.149 & -2.58 & 0.016 & 1.78 & 0.19 \\
SCAND Jun-Jul & -0.396 & 0.133 & -2.98 & 0.006 & 1.41 & 0.25 \\
\hline
\end{tabular}

2 